\title{
How Money Drives US Congressional Elections
}

\section{Thomas Ferguson, Paul Jorgensen, and Jie Chen ${ }^{1}$}

\author{
Working Paper No. 48
}

\author{
August 1, 2016
}

\begin{abstract}
This paper analyzes whether money influences election outcomes. Using a new and more comprehensive dataset built from government sources, the paper begins by showing that the relations between money and major party votes in all elections for the U.S. Senate and House of Representatives from 1980 to 2014 are well approximated by straight lines. It then considers

\footnotetext{
${ }^{1}$ Thomas Ferguson is Emeritus Professor at the University of Massachusetts, Boston, Senior Fellow at the Roosevelt Institute, and Director of Research at the Institute for New Economic Thinking. Paul Jorgensen is Assistant Professor of Political Science at the University of Texas Rio Grande Valley. Jie Chen is University Statistician at the University of Massachusetts, Boston. The authors gratefully acknowledge support from the Institute for New Economic Thinking for work on the database, but the paper represents the views of the authors, not any institutions with which they are affiliated. Jorgensen is grateful for support from the Edmond J. Safra Center for Ethics at Harvard University, where he was a Fellow. The entire Political Money Project database for this essay is to be freely available to the public when work on it is completed.

An early version of the paper was presented at the Institute for New Economic Thinking Annual Conference in Paris in April 2015. The authors are grateful to Edward J. Kane and Benjamin Page for exceptionally helpful comments on this version of the paper and would also like to thank Francis Bator, Walter Dean Burnham, Andrew Gelman, Irene Hueter, and Peter Temin for discussions of the earlier version. We are also grateful to Peter Ebbes for swift replies to queries and advice on programming and technical issues.
} 
possible challenges to this "linear model" of money and elections on statistical grounds, resting on possible endogeneity arising from reciprocal causation between, for example, popularity and votes. Extending the analysis of latent instrumental variables pioneered by Peter Ebbes and recently analyzed by Irene Hueter, the paper tackles this much discussed problem by developing a spatial Bayesian latent instrumental variable model. Taking a leaf from discussions of event analysis in economics and finance, the paper also examines the light thrown on the model's usefulness by studying changes in the gambling odds on a Republican takeover of the House in 1994. Both approaches suggest that reciprocal causation may happen to some degree, but that money's independent influence on elections remains powerful. A concluding section of the paper considers the alleged "centerist" leanings of American large corporations by comparison with members of the Forbes 400 and evidence that the effect of money in House elections has dropped slightly over time, though it remains extremely strong.

JEL Codes: No. D71, D72, G38, P16, N22

Keywords: political money, regulation, elections, political economy, United States government, campaign finance 


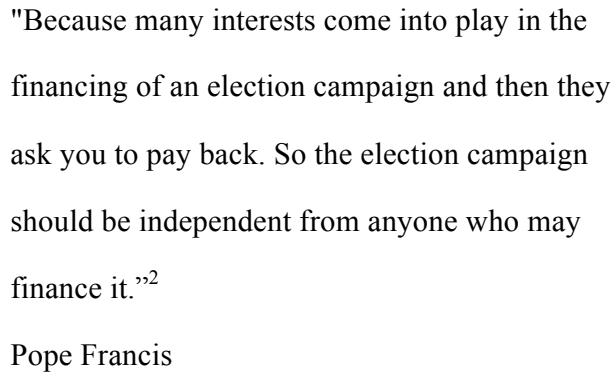

The protesters who swirled into parks, churches, and town squares around the world in the fall of 2011 to challenge the primacy of the " $1 \%$ " hammered relentlessly on one theme above all others: that economic inequality has deep roots in the political system. Many social scientists and intellectuals who have picked up from where the Occupy movement left off share this conviction; they, too, have broken with the taboos that for so long segmented discussions of politics from economics. Piketty, in his monumental study, for example, avows that income distribution is a basically a question of "political economy" not pure economics. Stiglitz in The Price of Inequality is equally forthright - "increasingly, and especially in the United States, it seems that the political system is more akin to 'one dollar one vote' than to 'one person one vote." "3

But concrete analyses of how political power combines with economic forces to secure the interests of the wealthy are few and far between, not only in these exemplary works, but almost everywhere else. In the social sciences, old habits, especially if they derive from the Cold War, do not die simply because someone thinks they should; and it is dismaying to see how

\footnotetext{
${ }^{2}$ Pope Francis, quoted in Ansa en Vatican, March 10, 2015; available on the web at http://www.ansa.it/english/news/vatican/2015/03/10/pope-calls-for-free-election-campaigns 35296d5c-c578-4ea4babe-e9cb9f520bb1.html The original has an extra quotation mark in the middle, which appears to be a misprint. Note that this is a report of the Pope's interview with a Brazilian slum newspaper and not the original. ${ }^{3}$ (Piketty, 2014; Stiglitz, 2013).
} 
easily even very able economists confuse measures promoted by banks with genuine responses to voter concerns, or how historians keep repeating claims about Presidential decisions that archival research exploded years ago. ${ }^{4}$ Disciplinary lags powerfully aid this research stagnation: Historians routinely ignore economics and, even after 2008, economics still mostly turns a blind eye to history. Political science fails to take advantage of newer techniques such as event analysis or recognize the steadily growing empirical evidence about party and candidate differences in investor coalitions - clearly because that would require recognizing that such coalitions exist. $^{5}$

But these clouds come with a silver lining. In our new Gilded Age, many features of the political landscape point so obtrusively to the dominance of the superrich that the real state of affairs is hard to miss without special training: $\$ 100,000$ a plate fundraising dinners to kick start presidential campaigns, Secretaries of the Treasury whose pockets bulge with bonus payments from past employers if they leave for "public service"; revolving doors between Congress and the private sector that whirl 24/7; or the surge in Congressional incomes, stock portfolios, campaign expenditures, loans, and perks since the sixties - these are facts that no amount of spin can hope to efface. ${ }^{6}$

Still, the absence of clear empirical accounts of how social class and big money directly translates into political dominance at the ballot box holds the door open to much mischief. In election years in particular, a kind of unholy alliance forms between the mainstreams of several social sciences, but especially political science and journalism. As spending on campaigns breaks all records, Super Pacs proliferate down to state and local levels, and corporations pour money

\footnotetext{
${ }^{4}$ See, for example, the discussion in (Ferguson \& Johnson, 2009) p. 31, Note 2, on the otherwise very stimulating work of (Mian, Sufi, \& Trebbi, 2008). More striking are the raft of works that attempt to discuss the 1931 world economic crisis without mentioning that the basic framework of famous Hoover Moratorium was handed to the President on a platter by Thomas Lamont of J.P. Morgan \& Co. - a fact that the banker and the President then tried to conceal. See the discussion of the telephone transcripts found in the Lamont Papers at Harvard Business School in (Ferguson, 1995a) That essay was first published in 1984, but recent discussions by a number of quite excellent economic historians pass over the fact or even claim that Hoover acted independently of the bankers. Cf. (Eichengreen, 2015) and (Tooze, 2014).

${ }^{5}$ See, e.g., the tables in (Ferguson, Jorgensen, \& Chen, 2013) or (Ferguson, 1995b).

${ }^{6}$ For the Treasury Secretary bonus and revolving doors, see, e.g., (Bloxham, 2014); (Blanes i Vidal, Draca, \& FonsRosen, 2012); for stocks and tips, see (Ziobrowski, Cheng, Boyd, \& Ziobrowski, 2004) and (Ziobrowski, Boyd, Cheng, \& Ziobrowski, 2011), inter alia. (Tahoun and Vasvari, 2016) show how bank lending to members of Congressional committees supervising financial institutions immediately jumps when they begin serving on these committees.
} 
into 527s and any numbers of other vehicles, the two groups keep insisting that seeing should not lead to believing.

Money, they protest, just does not matter very much in elections. A recent paper commissioned by the Campaign Finance Institute/BiPartisan Policy Center Working Group on the Money in Politics Research Agenda is representative:

There is something of a scholarly consensus at least for campaign spending in congressional races. However this consensus stands in stark contrast to the popular wisdom echoed by pundits, politicians, and reform advocates that elections are essentially for sale to the highest bidder (spender). Decades of social science research consistently reveal a far more limited role for campaign spending. Early studies tended to find that spending by challengers was far more effective than incumbent spending. More recent work argues that in principle campaign spending is equally productive across candidates, but that there are strongly diminishing marginal returns to campaign spending. Since most challengers spend less than incumbents, their spending is marginally more effective, even though the underlying "production function" that transforms money into votes is not different for challengers. Further, the best efforts at identifying the treatment effect of money in congressional races yield fairly similar substantive results: candidate spending has very modest to negligible causal effects on candidate vote shares. ${ }^{7}$

Such analysts are nothing if not consistent. Over the last few decades, their claims that American politics would be better off if more money flowed to political parties (rather than "outside" independent groups) have provided cover for leaders of both major parties to dismantle one barrier after another to the political system's equivalent of crack cocaine. Their efforts have also helped distract attention from the obvious question of why all those nice people in expensive suits and dresses keep pouring money into the political system. ${ }^{8}$

\footnotetext{
7 (Milyo, 2013).

${ }^{8}$ See the sample of views put forward in the symposium prefaced by (Krasnow, 2004); also (La Raja, 2013). This campaign for still more money for the parties was recently crowned with success. A provision in a bill passed with support from both the White House and Congressional leaders in December 2014 vastly expanded the amount of money parties can collect. This was part of the same measure gutting the most important provision of what was left of the Dodd-Frank financial reform legislation. See the discussion in, e.g., (Burnham \& Ferguson, 2014); for the party financing changes, see, e.g. (Parti \& Pallmer, 2015). Note that Tea Party representatives strongly opposed the provision as an effort by the GOP establishment to weaken them, which is exactly what it was. Democrats supported the measure for the usual reasons; in neither case were desires to turn back power to the people at all relevant. From an investment theory perspective, of course, the idea that expecting more money from millionaires will make parties more responsive to average citizens is a contradiction in terms and what happened in the 2016 election cycle is only to be expected.
} 
Thus reassured, journalists pitch in, sometimes after pausing to pat themselves on the back for courageously defying conventional wisdom. Often, our research suggests, at just about the point in campaigns where the size distribution of political contributions swells to elephantine levels, pundits extoll the importance of small donors to political campaigns. ${ }^{9}$ Recently a few, once again echoing social scientists who claim to know, add a new twist. Acknowledging that some large donors cluster at the extremes of the political spectrum, they nevertheless insist that these individuals are unrepresentative of the corporate mainstream. America's large firms, runs the line, tend to the political center. Supporting candidates of movements like, for example, the Tea Party, is not their thing; major corporations do not stoop to conquer. ${ }^{10}$

Two years ago we published research indicating that such views were badly mistaken. ${ }^{11}$ Drawing on a new data base that unified the separate reporting systems of the Federal Election Commission (FEC) and the U.S. Internal Revenue Service (IRS), we looked in detail at patterns of corporate giving in presidential contents. Inspired by an "investment" approach to political competition emphasizing the "money-driven" character of contemporary political systems, we also looked at Congressional elections. We deliberately employed Occam's Razor: We broke with customary practices of sorting out how incumbents or challengers fared in favor of direct tests of the global relationship of campaign expenditures to outcomes, while trying to take better account of total spending in campaigns, including the bourgeoning flows of outside "independent" spending. The idea was to start with a bivariate model, impose zero coefficients on any other term that belonged in the equation and gradually fill out the model.

Our results surprised even us and we devoted considerable space to reciting the usual litanies about the pitfalls of confusing correlation and causality. We found that in three widely spaced years - 1980, when Congress functioned very differently than it does today, 1996, and 2012 - the relation between major party candidates' shares of the two party vote and their proportionate share of total campaign expenditures were strongly linear - more or less straight

\footnotetext{
${ }^{9}$ See for references and discussion, (Ferguson et al., 2013).

${ }^{10}$ See, e.g., (Drutman, 2015) On the academic side, see, e.g., (Bonica, 2013) This latter raises a complex set of methodological and substantive issues we propose to examine in the near future.

${ }^{11}$ (Ferguson et al., 2013).
} 
lines, in fact. ${ }^{12}$ The relationship was strong for the Senate and almost absurdly tight for the House. $^{13}$

We also exploited our new, unified dataset to identify contributors whose names and addresses differed, but who were in fact the same people, and linked them to businesses they managed or controlled to produce far more accurate estimates of the true concentration of campaign contributions. We demonstrated, for example, that the $1 \%$-- defined quite carefully dominated both major parties; at the same time, however, our results once again directly confirmed the huge differences in the extent to which specific sectors and blocs of firms within big business differentially support Democrats or Republicans. The results point up the futility of trying to understand the dynamics of American politics without reference to investor coalitions and strongly support a broad investment approach to party competition. We showed that the case of the Tea Party was no different by tracking the rates of support for its candidates within business as a whole but, most importantly, within big business. Claims that major American businesses do not financially support Tea Party candidates are plainly false. ${ }^{14}$

This paper extends and consolidates our work on Congressional elections and campaign money. The discussion is in three parts. We begin with an overview of what is distinctive about the data. In the second section we show that the basic "linear" model we developed for analyzing our first sample of Congressional elections holds for all but one of them, both House and Senate, from 1980 to $2014 .^{15}$ (The single apparent exception, the 1982 Senate elections, is discussed below; by most social science criteria, the model does well; its divergence from the pack is only relative.) By itself this result raises basic questions about social science discussions of campaign finance, which overlooked this stark relationship for more than a generation.

\footnotetext{
${ }^{12}$ This statement needs qualification. As discussed below, Congressional districts exist in distinct geographic spaces. They are nearer some and further from others. This opens the door to the possibility of spatial autocorrelation, which can create difficulties for statistical estimation quite like the better known case of temporal autocorrelation. From the outset, we were clear about this possibility and tested for it, though such tests are not common in the vast literature on the subject. In most cases, we found spatial autocorrelation present and corrected for it in our estimates. This means that our models are not in fact purely "linear"; but because they still graph as straight lines, we employ the term for its ease in communication.

${ }^{13}$ The fewer number of cases makes the precision of the Senate estimates looser and the fit is in any case not as tight. We conjecture that this has something to do with the great publicity Senate races normally attract. One way of regarding the media influence is as a special case of another industrial sector.

14 (Ferguson et al., 2013).

${ }^{15}$ We repeat the qualification about our use of "linear" here.
} 
The third section of our paper discusses some implications of our findings and examines possible objections. We consider almost fifty years of strong direct relationships between money and Congressional outcomes to be powerful evidence in favor of a broad investment approach to party competition - evidence we believe no one would have expected from mainstream discussions of money's role in elections. But there are, for sure, reasonable counterarguments. In particular, there is one last redoubt in which skeptics can take refuge: the possibility that money and votes are reciprocally related. As Jacobson artfully frames the conundrum that protects this escape hatch: "Money may help win votes, but the expectation that a candidate can win votes also brings in money. To the degree that (expected) votes influence spending, ordinary measures will exaggerate the effects of spending on votes." 16

Our response to this challenge consists of two parts. Firstly, at least one clear natural experiment exists, in which it is possible to say with reasonable certainty that a tidal wave of money helped produce a shocking political upset that was anticipated by scarcely anyone: The famous 1994 election in which Newt Gingrich and a Golden Horde of donors stunned the world by seizing control of the House of Representatives for the Republicans for the first time since 1954 (and only the third time since 1932). Taking a leaf from recent studies in economics and finance of event analysis, we use published estimates of the change in the odds of a Republican takeover to rule out appeals to confident expectations of taking over the House as the explanation for the wave of money that drowned House Democrats that year. ${ }^{17}$

But 1994 is only one case, though admittedly a momentous one. We have not been able to locate usable odds compilations for other elections. In the hope of bypassing tedious debates over a host of less clear cut cases, we searched for more general approaches. Customary econometric techniques for resolving puzzles about reciprocal causation (one of several forms of statistical "endogeneity") rely on so-called "instrumental" variables. Good instrumental variables, however, are elusive; the criteria are demanding and dismayingly uncertain - in the end, what decides the value of the study is usually whether anyone can think of compelling

\footnotetext{
${ }^{16}$ (Jacobson, 2013) p. 51.

${ }^{17}$ On event studies, the literature is now copious, see, e.g., (Faccio, Masulis, \& McConnel, 2006) or (Ferguson \& Voth, 2008).
} 
reasons why the instrument might be contaminated. ${ }^{18}$ Given all the controversies, such a practice would make us uneasy in even the best of cases, but there are good reasons for thinking that elections pose peculiarly daunting challenges to applications of the method. Even analysts who once were optimistic express increasingly deep misgivings about the welter of claims and counter-claims in the journals. ${ }^{19}$

We suspect that where politics and money is concerned, the search for good instruments is in most instances akin to hunting the Snark. A better approach is to search for estimation methods that do not require us to lean so heavily on thin reeds. This quest led us to the work of Peter Ebbes and his colleagues. ${ }^{20}$ Ebbes and his associates have developed latent instrumental variable (LIV) models into a practical working tool, where the instrument is unknown, and used them to attack a variety of problems.

These methods are relatively new and, of course, like virtually all statistical tools, rely on assumptions for their validity, but the assumptions required do not appear any more farfetched than more conventional approaches to tackling the question. Irene Hueter's recent critical review is very helpful in clarifying important points. While critical on various secondary issues, she concludes that the method appears to be fundamentally sound and to work in practice: the solutions it gives to some classical econometric applications appear reasonable and in line with results using more traditional methods. ${ }^{21}$ We think it is time to try the approach on money and politics, particularly since we can crosscheck its findings with our results on 1994, obtained by the completely different approach now conventional in finance

Our data, however, differ from the cases to which such models have thus far been applied. As discussed below, spatial autocorrelation marks much of our data - some Senate elections and virtually all House contests. We, accordingly, cannot without checking simply employ an off the shelf model; the task requires the development of a spatial latent instrumental variable model. Section 3 of the paper estimates such a model using Bayesian

\footnotetext{
${ }^{18}$ See, e.g., (Stock \& Watson, 2010).

${ }^{19}$ (Jacobson, 2006), p. 197. (Bartels, 1991).

${ }^{20}$ (Ebbes, 2004); (Ebbes, Wedel, Boechenholt, \& Steerneman, 2005) See also (Zhang, Wedel, \& Pieters, 2009); (Rutz, Bucklin, \& Sonnier, 2012).

${ }^{21}$ (Hueter, 2016).
} 
(SBLIV - Spatial Bayesian Latent Instrumental Variable) methods. Lest we be misunderstood, the point of this model is not to deny that reciprocal causality happens, but to fix the extent of the endogeneity and arrive at more precise estimates of money's effects. Our results suggest that the coefficients for the influence of money usually drop, but not by that much. They remain strong, with results for 1994 that are consistent with the test on that year inspired by event analyses.

The final sections of our paper look briefly at the extent to which major American corporations support political extremes. (On the right; claims about "left wing billionaires" can be brushed aside; essentially no major American corporations or members of the Forbes 400 support union drives or a fortiori, politicians like Vermont Senator Bernie Sanders. ${ }^{22}$ ) For reasons we lack the time to recount here, we are skeptical of published scales that purport to measure the left/right proclivities of major investors and corporations. We also believe that notions that major corporations are "centerists" are profoundly misleading. We accordingly look at how changing the focus from, for example, contributions from corporate political action committees (PACs) to more synoptic measures that more fully reflect the range of ways corporations and the super-rich contribute to campaigns alters these now familiar claims. Our test is very simple, but the results are dramatic: Far from reflecting the proclivities of eccentric billionaires, groups like the Tea Party are far more likely to win support from America's large corporations than the members of the Forbes 400. Our results illustrate how relying on studies of campaign finance that rely on subsets of data such as PACs distort the full range of major corporate giving and underscore our earlier conclusions about the importance of sectoral and firm differences in analyzing politics. At the end of the paper, we illustrate and discuss a striking fact about the effect of money on election outcomes our analysis discloses - one that we are the first to admit is a puzzle.

\section{Data on Political Money}

All discussions of campaign money need to begin with the caveat that political money strongly resembles the electromagnetic spectrum: Only slivers of it are visible to the naked eye and even that portion is shrinking as so-called "Dark Money" proliferates in the electoral

\footnotetext{
${ }^{22}$ Because of the huge amount of data processing, our review of the 2016 election cycle money is far from complete; but for an interim assessment, see (Ferguson, 2016). See also the discussion of specific sectors of the American dual economy in (Temin, 2016).
} 
system. ${ }^{23}$ On the other hand, in the United States, though not everywhere else, the visible part of the spectrum is large and important: analyzing it yields insight into flows of funds that play truly significant roles in the system. The now celebrated category of "Dark Money" - money that anonymous donors launder through public "charities" that are not required to report where the money came from - is less of a threat to many of our inquiries than one might suppose. Most Dark Money briefly surges above ground as it transits to campaigns from the "charities" that ladle it out. The latter report their spending, if often carelessly, just not who gave them the funds. Inquiries into total spending (the focus of our linear model) are thus not affected, though estimates of donor concentration and total contributions in the later part of our paper perforce become floors, not ceilings.

For this paper, the thornier data problems arise from the fragmentation of reporting sources and formats - whose chaotic realities are, we are sure, a major reason why progress has been so slow in understanding campaign finance. Because we have extensively discussed elsewhere the measures we have taken to overcome these problems, our discussion here will be summary, with a more formal presentation relegated to Appendix $2 .^{24}$

The data we use in this study come from our larger Political Money Project. The guiding idea of that effort is to return to the raw data made available by the FEC and the IRS and create a single unified database as far back as the data exist containing all contributions in whatever form for all federal elections. This is a tall order, as anyone familiar with our vastly different data sources will realize. In particular, FEC sources are sometimes jarringly inconsistent; many previous analysts do not always appear to recognize the extent of the "flow of funds" problems in this data, nor the pitfalls besetting efforts to track money split up at joint campaign events. Nor are all the contributions in the IRS database available in electronic form for all years. ${ }^{25}$

\footnotetext{
${ }^{23}$ For "Dark Money," see e.g., (Mayer, 2016). For the broader "spectrum of political money" see (Ferguson, 2015b), which offer some estimates of the money value of each category. That discussion is a warning against notions that formal political money is the only important form of money driving policy. See also (Ferguson \& Johnson, 2013), Figure 7.3, p. 88, which illustrates how sheer economic inequality can by itself break down formally democratic systems.

${ }^{24}$ (Ferguson et al., 2013).

25 (Ferguson et al., 2013).
} 
But our real work commences only once this stage is completed. At both the FEC and the IRS, standards for reporting names of both individual and corporate contributors are laughably weak. Both companies and individuals routinely take advantage of regulatory nonchalance about even arrant non-compliance. Along with an enormous number of obviously bad faith reports (such as presidential contributions listed as coming from individuals working at banks that were swallowed long ago by other giants) all sorts of naïve, good faith errors abound in spelling, consistent uses of Jr., Sr., or Mr., Ms., and Mrs., along with myriad incomplete entries and hyphenated names. Many people, especially very wealthy contributors, legitimately have more than one address and fail to consistently list their corporate affiliations ("retired" as a category of contributor is extensively abused; some people who chair giant corporations often claim the status). It does not help that, as we discovered, the FEC has on occasion eliminated important data without publicizing this fact. ${ }^{26}$

From the outset we recognized that solving this problem was indispensable to making reliable estimates of the concentration of political contributions. We adapted for our purposes programs of the type used by major hospitals and other institutions dealing with similar problems, adding many safeguards against tricks that no medical institution ever has to worry about, all the while checking and cross-checking our results, especially for large contributors. In big data efforts, there is never a point where such tasks can be regarded as unimpeachably finished. ${ }^{27}$ But we are certain that our data substantially improve over other sources on offer, including rosters of campaign contributions compiled by for-profit companies and all public sources.

Because we can compare many reports filed by people whom we can recognize as really the same person, we are able to see through schemes, such as those encouraged by the Obama campaigns (especially in 2008) to encourage individual contributors to break up contributions into what looks like many "small" donations. ${ }^{28}$ We are also able to fill in many entries for workplace affiliation left blank. By itself, these steps lead to quantum leaps in the number of

\footnotetext{
${ }^{26}$ See (Ferguson, Jorgensen, \& Chen, 2012c); (Ferguson, Jorgensen, \& Chen, 2012a); (Ferguson, Jorgensen, \& Chen, 2012b), which also deal with the FEC response. We have checked and the data whose removal we criticized are back in.

${ }^{27}$ Note that by many standards of "big data" even the data sets we use here are fairly small.

${ }^{28}$ See the discussion in (Ferguson et al., 2013).
} 
contributions coming from the same enterprises. But we have also used business directories and data from the Securities and Exchange Commission to pin down the corporate affiliations of many other contributors, whose identifications, once established, are similarly extendible.

These efforts allow us to take another step beyond existing discussions of political money. We aggregate all the data by "investing units." For the first time, this brings together contributions from executives, corporate treasuries (especially the often gigantic " 527 " donations), political action committee contributions, and recognizes that they are all coming from the same companies. Not surprisingly, this move dramatically changes the scale of the political landscape and estimates of concentration. This process is extremely time consuming, however, and can only in part be automated. We completed and used one full database of this type for our study of the 2012 election; the process is not complete for many of the elections discussed in this paper, as we will discuss.

\section{Models of Congressional Elections}

Because this paper focuses on the effect of total expenditures on election outcomes, incompleteness of investor aggregation does not matter; where it does, as in our discussion of contributions to Tea Party candidates, we employ the data we compiled for the 2012 election cycle, which is complete. $^{29}$

Otherwise we build up our data as outlined in Appendix 2. As we explain there, the data reports produced by the FEC have evolved markedly over time. In part, these changes arise from legislation and court rulings that redefine allowable forms of expenditure and receipts, but they also derive from changes in FEC reporting conventions. Among these latter, alterations in the way the FEC reports congressional campaign financing in 2008 and after are especially important. These make retrieving total expenditures harder: One has to ferret out money flows, such as different forms of independent expenditures and electioneering communications that previously were reported more accessibly. ${ }^{30}$

\footnotetext{
${ }^{29}$ Note that this election cycle predated subsequent clashes between, for example, the U.S. Chamber of Commerce and the Tea Party. That clash we intend to treat separately.

${ }^{30}$ Depending on the precise year are in question, these forms of spending may reflect inflows from $527 \mathrm{~s}$ or Super Pacs. If the money mentions specific candidates, they are supposed to show in that data. There is perhaps one form
} 
Data compiled like this allows us to brush past artificial efforts to distinguish kinds of spending in Congressional races, such as "inside" vs. "outside" funds (that is, spent by candidate's own committee or by allegedly "independent" outside groups) or the spending of challengers or incumbents, and directly test global hypotheses about political money and elections. We can pool all spending by and on behalf of candidates and then examine whether relative, not absolute, differences in total outlays are related to vote differentials. This way of attacking the problem sidesteps many issues about defining spending in differently sized districts, such as dollars per voter, that lose the forest in the trees. ${ }^{31}$

If conventional claims about the limited importance of political money are correct, then the individual data points - particular House or Senate election outcomes -should be scattered indifferently across a graph. Money just wouldn't predict voting outcomes very well. If on the other hand, money is strongly associated with votes received, then the fit would approximate a straight line. All kinds of intermediate cases, of course, can be imagined. ${ }^{32}$

Figure 1 shows the actual result for House elections in 2012. It displays a strongly linear relationship between Democratic candidates' shares of total two party spending in House

of expenditure that is not fully caught in our totals: issue ads that don't name any candidate. We have not found it possible to identify these from 527 reports themselves; the detail usually is not there. We believe this form of expenditure is relatively exiguous by comparison with what we are able to identify.

${ }^{31}$ Besides being very intuitive, using percentages within individual races makes it unnecessary to calculate dollars per voter and many other measures that preoccupied some researchers and that lead to vastly different measuring rods.

${ }^{32}$ The votes measure is: [(\#Dem Votes)/(\#Dem Votes + \#Rep Votes)] - [(\#Rep Votes)/(\#Dem Votes + \#Rep Votes)]. For money, we capture all candidate disbursements of the two major parties (House and Senate) and all outside-the-candidate spending in the district/state that is known/measured.

a. $\quad$ Pro DEM Money = DEM Disbursements + All Independent Expenditures For DEM + Communication Costs for DEM + All Party Coordinated Expenditures for DEM + Identified Electioneering for DEM

b. Against REP Money $=$ All Independent Expenditures against REP + Communication Costs against REP + Identified Electioneering against REP

c. $\quad$ DEM $\%$ of Total Two Party Money $=$

i. $\quad[$ (Pro DEM Money + Against REP Money) / (Pro DEM Money + Against DEM Money + Pro REP Money + Against REP Money)]

See the discussion in Appendix 2. Note that this definition works for districts that have major parties competing. A very few states sometimes have run off elections in which several candidates of one party compete; these we do not include. 
Figure 1

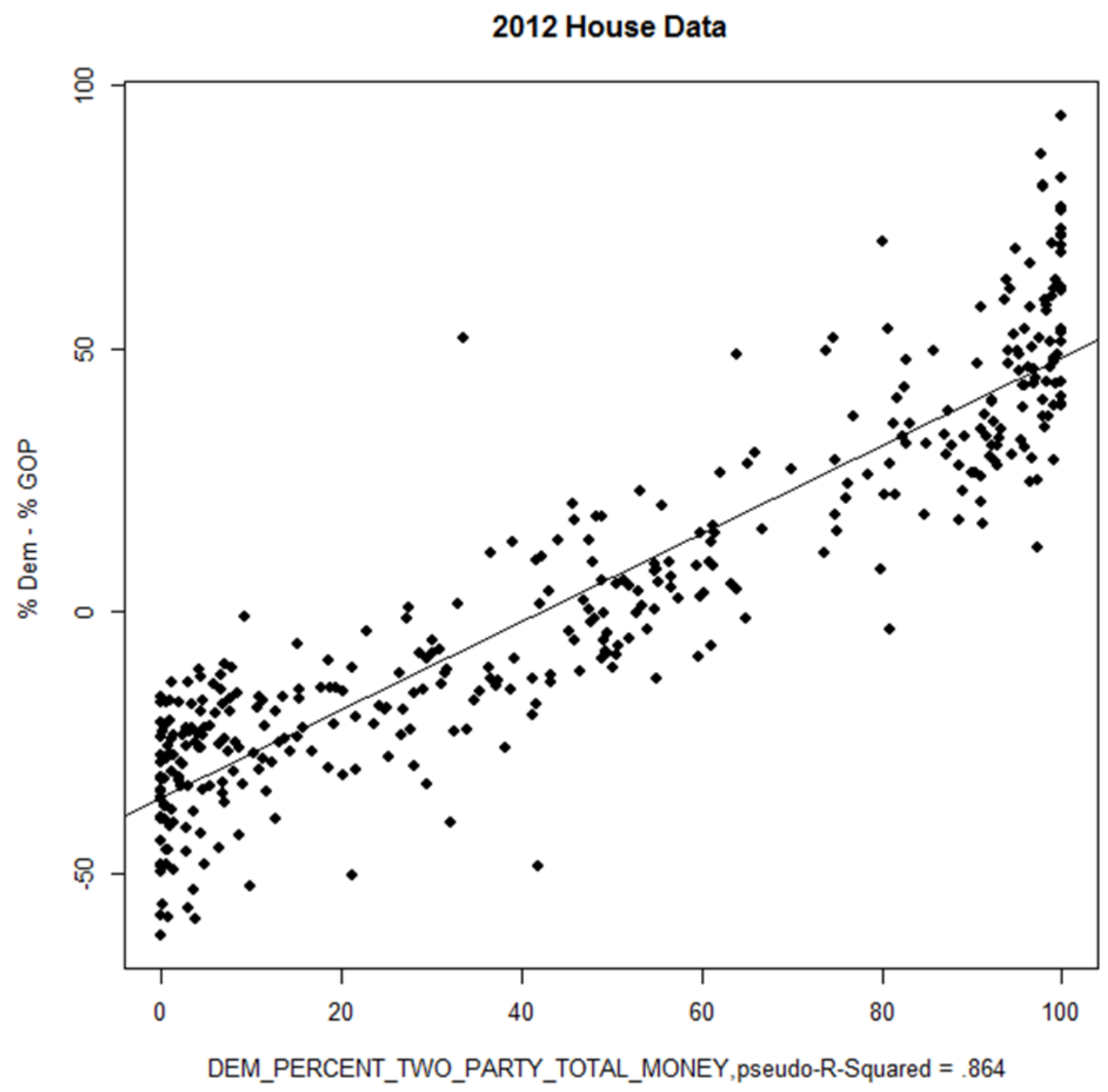


elections and the percentage of major party votes they won. (At the bottom left Democrats spend almost no money and get virtually no votes; at the top right, they spend nearly all the money and garner virtually all the ballots, calculated as proportions of totals for the major parties. ${ }^{33}$ )

Suspicious that this result was too good to be true, we ran more tests. Congressional districts exist in definite physical spaces at varying distances from each other. Though much of the literature on Congress brushes past this fact, such "spatial autocorrelation" can affect the accuracy of statistical estimates rather like temporal autocorrelation does. We accordingly ran Moran tests to check for this. In most House elections and some Senate contests we found spatial autocorrelation was indeed present. We thus dropped ordinary least squares approaches to estimation in favor of spatial regressions. Usually these only improved the fit, though not by much. $^{34}$

House elections provide hundreds of data points for every election; our results for these, accordingly, were relatively robust. By constitutional design, however, Senate elections are far fewer and deliberately staggered; typically only a third of that body's 100 seats are in play in a single election. This inevitably makes our results less tight and reduces statistical reliability, but the basic approach is once again vindicated, with the qualification that in Senate races the relation between money and votes appears to be somewhat looser than in the lower house. ${ }^{35}$ Our conjecture was, and remains, that this is related to the differential press attention lavished on Senate elections.

Our customary reaction to all analyses of political behavior is to wonder how far back in time their results can be extended, since we agree with Burnham that a broad historical approach is the royal road to real comprehension. Alas, right now data of the type required for studies like ours go back only to 1980 . Still, we thought, data on elections from those earlier years might be

\footnotetext{
${ }^{33}$ An earlier version of our paper, presented at the Institute for New Economic Thinking Annual Conference in Paris, showed a figure including cases in which major party candidates ran without any opposition from the other major party; this led to an obvious pile up of residuals at each end. Our equation in this version of the paper drops cases with no major party challenger, reducing the bundling of residuals at each end ( 0 and 100). Nothing substantive changes.

${ }^{34}$ Political scientists unaccustomed to testing for spatial effects sometimes seize on the limited size of the effects to dismiss the whole exercise; but you can do this only after running the tests. In earlier work on other subjects, we have on rare occasion seen signs change.

${ }^{35}$ Spatial autocorrelation in Senate elections is also less common; see the discussion below.
} 


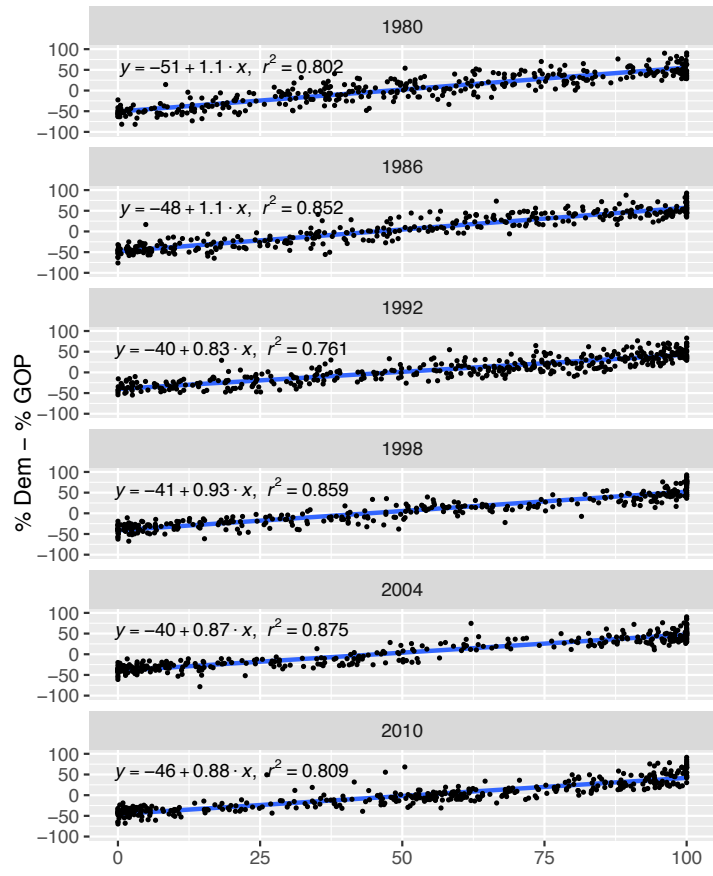

Figure 2: House Elections 1980 to 2014

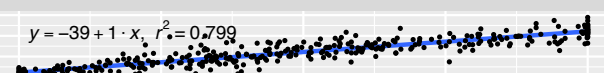

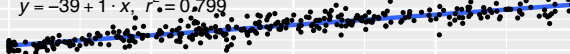

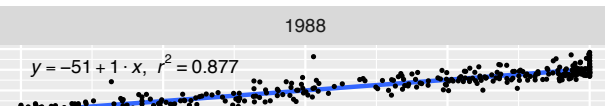

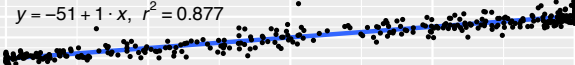
1994

$y=-54+0.95 \cdot x, r^{2}=.0 .808$

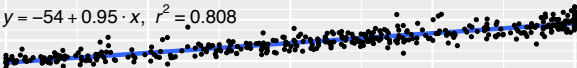

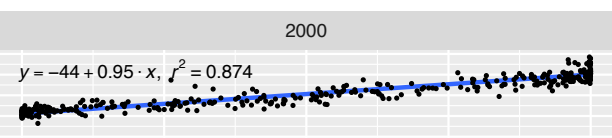

2006

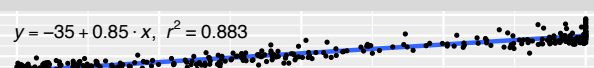

2012 $y=-36+0.84 \cdot x, r^{2}=0.841$.



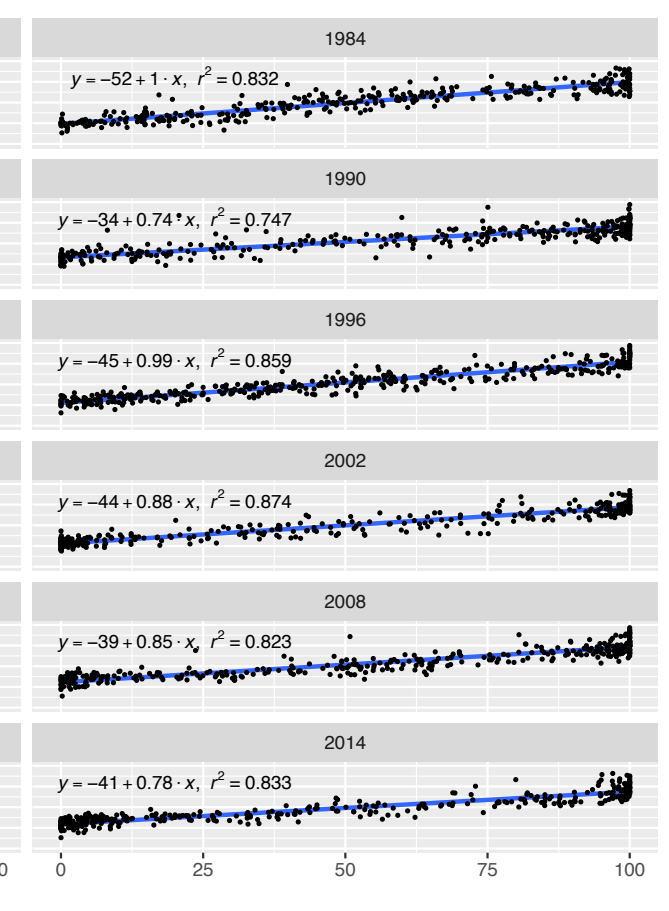




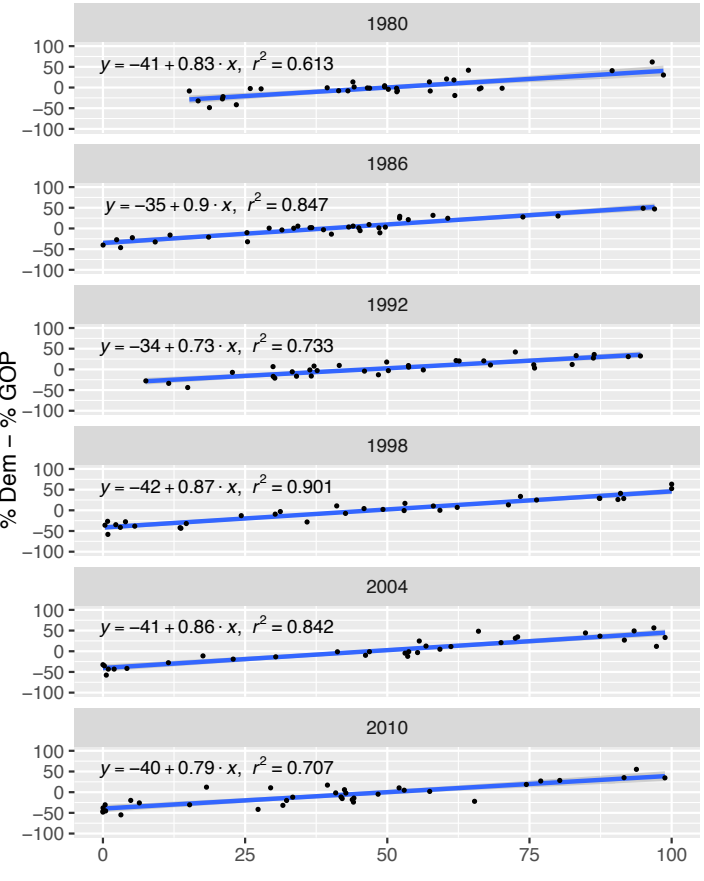

Figure 3:Senate Elections 1980-2014

Figure 3:Senate Electio
1982
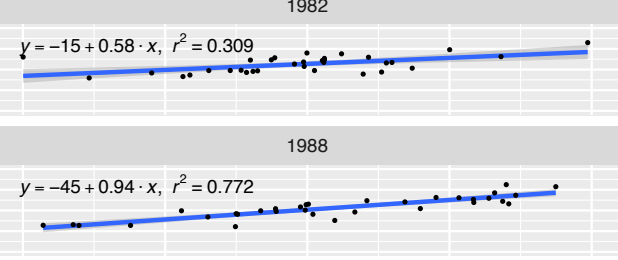

1994
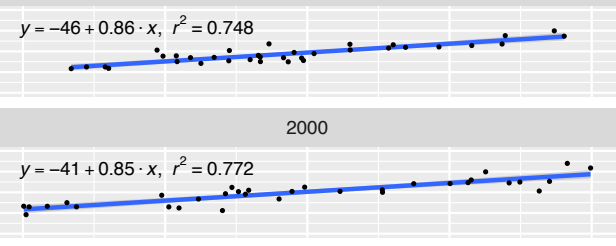

2006

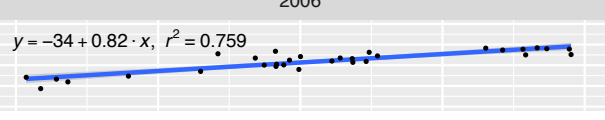

2012

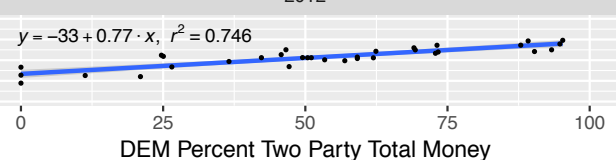

1984

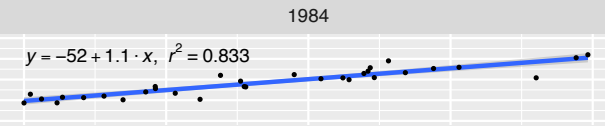

1990

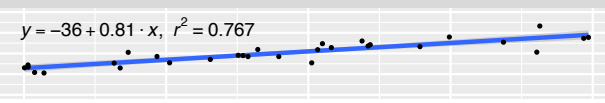

1996

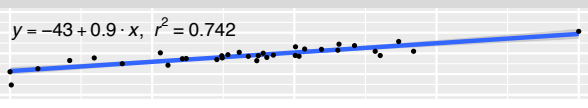

2002

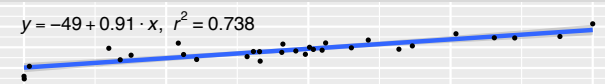

2008

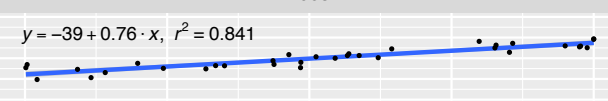

2014

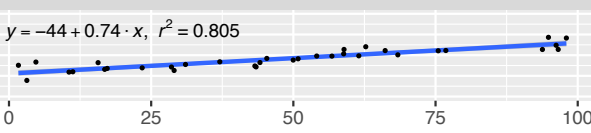


particularly interesting, because both elections and Congress itself functioned rather differently than in the nineties and, especially, now.

Our first studies, however, revealed that not only in 1980, but also in 1996, essentially the same linear results for spending and vote shares held. We now have compiled data for both the House and Senate in every election between 1980 and 2014 and estimated equations for all of them. Figure 2 displays graphs of the House elections; Figure 3 shows results for the Senate. Tables 1 and 2 set out the statistical results for elections in each chamber. They confirm that the patterns we found for 1980, 1996, and 2012 are not flukes. In all of them, our "linear" model works well. With the exception of the 1982 Senate elections, the results are extremely strong. (That election has one outlier, Wisconsin. If that is removed, the results fall into line with the rest, though the R-Squared is a bit less than usual. Our Figure 3, for Senate panels for that year show results with the outlier, Senator William Proxmire.) The conclusion has to be that spending by major political parties is indeed, at first sight, strongly related to the proportion of votes they win and has been for as long as we have data. We consider this finding, in its own right, to be a significant result. If the pattern had been noticed a generation ago, discussions of politics and money might have taken a different turn.

\section{Saving the Appearances?}

We are the first to admit that our evidence hardly amounts to controlled experiments. But we also think waiting for these is a pipe dream: The cost would be enormous and, considering experimental review requirements now common in universities, would require a substantial number of informed candidates willing to sacrifice their chances for election for the sake of knowledge as well as a sizeable group of billionaires interested in the same noble cause instead of controlling public policy.

By contrast, additional reflection on our evidence promises to be quite productive. We begin with a general caution. As discussed below, one can envisage various ways to attempt to explain our results away. But the testimony of a whole generation of elections should be a warning that such efforts are likely quixotic.

The sheer uniformity in the pattern is telling in its own right. It is hard to believe that the constancy over the length of time we have uncovered results from calculated responses ground 
Table 1: US House Elections Spatial Latent Instrumental Variable Model:

Estimated Coefficients of Mean and Median for Predicting the Percent of the Vote: \% Dem - \% GOP of Two Party Vote

\begin{tabular}{|c|c|c|c|c|c|c|}
\hline Year & OLS & Spatial Model & SBLIV4 & Psd Rsq & PV(I) & $\mathbf{N}$ \\
\hline 1980 & $1.062(.027)$ & $1.049(.027)^{b}$ & $1.058(1.005,1.112)$ & $.802 / .809$ & .000 & 382 \\
\hline 1982 & $.996(.026)$ & $.975(.027)^{\mathrm{a}}$ & $1.006(.955,1.055)$ & $.799 / .803$ & .042 & 376 \\
\hline 1984 & 1.011(.024) & $.989(.025)^{\mathrm{a}}$ & $1.010(.962,1.058)$ & $.832 / .836$ & .009 & 365 \\
\hline 1986 & $1.055(.023)$ & $1.038(.024)^{\mathrm{a}}$ & $1.051(1.005,1.098)$ & $.852 / .855$ & .027 & 361 \\
\hline 1988 & $1.031(.021)$ & $1.017(.021)^{\mathrm{a}}$ & $1.028(.787,1.248)$ & $.877 / .879$ & .013 & 354 \\
\hline 1990 & $.744(.023)$ & $.729(.023)^{\mathrm{a}}$ & $.746(.706, .787)$ & $.747 / .755$ & .015 & 350 \\
\hline 1992 & $.829(.023)$ & $.826(.024)^{b}$ & $.941(.790,1.174)$ & $.761 / .764$ & .009 & 400 \\
\hline 1994 & $.949(.024)$ & $.930(.024)^{\mathrm{a}}$ & $.943(.890, .995)$ & $.808 / .814$ & .004 & 389 \\
\hline 1996 & $.989(.020)$ & $.937(.021)^{\mathrm{a}}$ & $.960(.918,1.002)$ & $.859 / .870$ & .000 & 410 \\
\hline 1998 & $.932(.021)$ & $.900(.020)^{b}$ & $.900(.859, .942)$ & $.859 / .872$ & .000 & 341 \\
\hline 2000 & $.948(.019)$ & $.892(.019)^{\mathrm{a}}$ & $.898(.861, .935)$ & $.874 / .893$ & .000 & 370 \\
\hline 2002 & $.879(.018)$ & $.858(.019)^{\mathrm{a}}$ & $.868(.830, .905)$ & $.874 / .879$ & .001 & 354 \\
\hline 2004 & $.874(.017)$ & $.827(.018)^{a}$ & $.853(.819, .888)$ & $.875 / .889$ & .000 & 366 \\
\hline 2006 & $.851(.016)$ & $.825(.016)^{b}$ & $.832(.798, .866)$ & $.883 / .893$ & .000 & 374 \\
\hline 2008 & $.852(.020)$ & $.794(.020)^{\mathrm{c}}$ & $.804(.764, .843)$ & $.823 / .848$ & .000 & 379 \\
\hline 2010 & $.875(.021)$ & $.803(.021)^{a}$ & $.789(.748,832)$ & $.809 / .835$ & .000 & 406 \\
\hline 2012 & 838(.019) & $.770(.019)^{\mathrm{a}}$ & $.801(.762, .841)$ & $.843 / .864$ & .000 & 384 \\
\hline 2014 & $.783(.019)$ & $.732(.020)^{a}$ & $.747(.709, .785)$ & $.833 / .845$ & .000 & 357 \\
\hline
\end{tabular}


Note:

a: Spatial Lag Model (SAR)

b: Spatial Error Mode (SER)

c: Spatial Durbin Model (SDM) 
Table 2: US Senate Elections Spatial Latent Instrumental Variable Model:

Estimated Coefficients of Mean and Median for Predicting the Percent of the Vote: \% Dem - \% GOP of Two Party Vote

\begin{tabular}{|c|c|c|c|c|c|}
\hline Year & $\begin{array}{c}\text { OLS } \\
\text { Coefficients ( SE) }\end{array}$ & $\begin{array}{c}\text { Spatial Model } \\
\text { Coefficients( SE) }\end{array}$ & $\begin{array}{c}\text { SBLIV3 } \\
\text { Median ( } 95 \% \mathrm{CI})\end{array}$ & R-square & $\mathrm{N}$ \\
\hline 1980 & .827 & & $.835(.592,1.073)$ & .613 & 33 \\
\hline 1982 & $.582(.156)$ & & $.582(.267, .895)$ & .309 & 33 \\
\hline 1984 & $1.053(.086)$ & $1.012(.065)$ & $1.019(.900,1.140)$ & .833 & 32 \\
\hline 1986 & $.898(.068)$ & & $.899(.762,1.033)$ & .847 & 34 \\
\hline 1988 & $.942(.092)$ & & $.968(.775,1.152)$ & .772 & 33 \\
\hline 1990 & $.811(.084)$ & & $.812(.640, .982)$ & .767 & 30 \\
\hline 1992 & $.735(.078)$ & & $.735(.579, .892)$ & .733 & 34 \\
\hline 1994 & $.856(.087)$ & $.819(.073)$ & $.835(.661,1.011)$ & $.748(.774)$ & 35 \\
\hline 1996 & $.898(.094)$ & & $.897(.709,1.1083)$ & .742 & 34 \\
\hline 1998 & $.874(.052)$ & & $.883(.774, .984)$ & .901 & 33 \\
\hline 2000 & $.853(.083)$ & & $.856(.688,1.024)$ & .765 & 33 \\
\hline 2002 & $.910(.103)$ & & $.913(.703,1.124$ & .738 & 30 \\
\hline 2004 & $.864(.068)$ & $.864(.056)$ & $.893(.640,1.352)$ & .842 & 32 \\
\hline 2006 & $.820(.086)$ & & $.855(.641,1.085)$ & .759 & 31 \\
\hline 2008 & $.764(.059)$ & & $.758(.402, .959)$ & .841 & 34 \\
\hline 2010 & $.793(.089)$ & $.736(.084)$ & $.734(.559, .912)$ & $.707(.739)$ & 35 \\
\hline 2012 & $.771(.081)$ & & $.786(.610, .964)$ & .746 & 33 \\
\hline 2014 & $.742(.065)$ & & $.742(.624, .845)$ & .805 & 34 \\
\hline
\end{tabular}


Spatial Autocorrelation not so prevalent in Senate elections; Spatial Latent Instrumental Variable Model estimated only where tests indicated one was needed. Otherwise results for Latent Instrumental Variable Model are shown. Note that occasionally one or another state elected two Senators. 
out by political parties and factions, no matter how supple. Over the last few decades, American political finance has evolved extensively into a more top-down process, in which giant blocs of investors organize nationwide and work steadily with (or against) a relative handful of national political leaders, who themselves plainly strive to emulate the consumption habits of their multimillionaire backers. ${ }^{36}$ But even now this system's degree of centralization can be overestimated, as our evidence about the divergent paths charted by different sectors in 2012 and similar studies of earlier elections should forcibly remind everyone. ${ }^{37}$

In the 1980s and until at least 1994, by contrast, nothing approaching centralized fundraising machines with the capacity easily to move money around on the margins of national races existed. The closest things to these at the time were the phalanxes of millionaires that swept first Reagan and then George H.W. Bush to power, but these were centered on the White House. They did not extend to the national parties as a whole, especially the one that did not hold down the White House. Machines capable of bankrolling a broad array of Congressional campaigns were little more than glimmers in the eye of New Democratic leaders like Charles Manatt or Republican insurgents such as Newt Gingrich, though Gingrich's efforts represented a quantum leap in this respect. ${ }^{38}$

Neither party's Congressional flows of money probably ever approached the scale that would have been required to sustain the eerie regularities in our data. Especially given the inexactitude of real life, small sample polling done on the fly, and the infighting and disorganization that demonstrably attended so many campaign efforts then, not to mention the tendency of candidates to "over insure" their own campaigns, it is hard to accept that enough money could possibly follow polls so slavishly. Broadly and with sizeable lags, perhaps, but not to the degree suggested by the evidence. The requisite servo-mechanisms simply did not exist. Neither the information nor the organizational capacity for such activities existed; at best one could read tea leaves early in the race, put out the begging bowls, and then hope for the best while hyping any and all good news. Even long after 1994, party leaders recognized that polls were incapable of producing tight predictions until the last few weeks of campaigns; they thus

\footnotetext{
${ }^{36}$ See (Ferguson, 1995b), but especially (Ferguson, 2015b).

${ }^{37}$ For earlier elections, see the discussion in (Ferguson, 1995b); we also looked to see if Senate elections affected House races in states having the former, and did not find any effect.

${ }^{38}$ (Ferguson \& Rogers, 1986) for Manatt and for Gingrich, (Ferguson, 2015b).
} 
were uncertain trumpets for fundraising. ${ }^{39}$ And the relation between polls and seats in the House was only vaguely understood, becoming salient only after the 1994 shock of the Republican takeover of the House triggered a flurry of investigations. ${ }^{40}$ In the final days of all election campaigns, certainly, many efforts to top up deserving candidates happened, but again mostly on an imperfect, decentralized basis.

In at least one case the Argument from Design can be decisively rejected. In 1994, Newt Gingrich and a bloc of Republican insurgents launched a sweeping effort to take control of the House of Representatives. They had been building for this for at least a decade and there is no doubt at all that Gingrich and his fellow fundraisers extraordinaire, Haley Barbour and Phil Gramm (who was concentrating on the Senate) had deep ties to big business sectors that were by then on fire for sweeping deregulation and rolling back the whole New Deal regulatory state. ${ }^{41}$ But here is the point: Though later many chroniclers of retrospective history write the story by assuming its endpoint, at the outset Gingrich's quest to seize control of the House of Representatives was extensively a faith based operation. Hardly anyone thought they could actually do it, perhaps outside of the leaders themselves and possibly including some of them. On the morning after the election, the sense of shock was profound and worldwide, extending for sure even to Gingrich's major financiers, who doubtless had hopes, but no realistic expectations, of victory on the scale they had just won.

One of us witnessed how some of Gingrich's greatest donors reacted to the triumph and has never forgotten the joyous seismic shock that radiating through certain parts of Wall Street in the days after. Newspaper coverage of the episode confirms the general sense of stupefaction. But there is no need to take anyone's word for this.

In recent years, growing resort to event studies and arguments about how information affects expectations has led to intense discussions within economics and finance of judgments of probabilities and expectations. Within those fields a consensus has formed that published gambling odds are generally reliable indexes of expectations about probabilities. ${ }^{42}$ Early

\footnotetext{
39 (Rove, 2010).

${ }^{40}$ See, e.g., the references and discussion in (Moore \& Saad, 1997).

${ }^{41}$ (Ferguson, 2015a); see also (Jorgensen, 2013).

${ }^{42}$ (Snowberg, Wolfers, \& Zitzewitz, 2012) Note what is not claimed here: that gambling odds are superior to, say, polls, as predictors of elections or actually represent a perfect or near perfect way of aggregating information. We
} 
objections that common vehicles like the Iowa Electronic Markets were too thin to be reliable and subject to manipulation have been investigated and rejected. ${ }^{43}$ Some champions of this new approach to "information aggregation" have even suggested that such markets are superior to polls for forecasting elections.

To many researchers in other fields, such as political science, these claims often seem fantastic, especially when they are advanced as part of a larger case on behalf of free market fundamentalism and "perfect markets." But we believe it is a big mistake to let the exaggerated claims distract from the real contributions of these discussions. As Wolfers and his colleagues have indicated, the evidence of fruitful application is abundant. Anyone familiar with the research should see that economics and finance have much to contribute here: ${ }^{44}$ While we flatly reject all forms of "rational expectations" arguments and the entire decision making theory that justifies it, we have no quarrel with the use of odds as clinical evidence about consensus expectations. ${ }^{45}$ They are superior to guesses, especially by researchers who almost never take the time to immerse themselves in details.

Unfortunately, finding usable odds quotations for our purposes is difficult: one would normally require a large number of quotations for individual races and these are just not to be had. But our search turned up one set of published odds that is truly revealing because of the special circumstances that it represented.

A widely used source for political campaign odds, the Iowa Electronics Markets, has a complete series of contract quotations reflecting changing expectations for control of the House down to Election Day, 1994. At the start of the campaign, the Democrats had held continuous control of the House of Representatives since 1955 and, indeed, with but two brief interruptions, since the 1932 election. As the campaign began, the published odds indicated the probability of

take the basic point of (Grossman \& Stiglitz, 1980) and do not favor turning commonsense points about practical information handling into metaphysical claims about cognition. But we also accept that if any sizeable body of opinion expected, for example, a Republican victory in 1994, it would have leaked into the odds quotations; the same goes for "secret" polls known only to party elites, though those can be ruled out on other grounds, since there were plenty of polls published that anyone could examine. Right to the end, for example, several ABC polls showed the Democrats ahead by substantial margins. See (Sherman, 2013).

${ }^{43}$ See (Rhode \& Strumpf, 2007); (Rhode \& Strumpf, 2008); (Rhode \& Strumpf, 2004).

${ }^{44}$ (Wolfers \& Zitzewitz, 2004); (Snowberg et al., 2012).

${ }^{45}$ See the common sense approach to event analyses spelled out in (Epstein \& Ferguson, 1991) or, less explicitly, in (Ferguson \& Voth, 2008). 
the Democrats retaining control of the House was about $80 \%$. After many months of campaigning and excited talk - that mostly attained notice only afterward - about Contracts with America, the probability had not budged much. Yes, there was a last minute blip in hopes for a Republican takeover - but the rise was tiny. There was no shift big enough to justify a huge wave of money based on the premise that an epoch making change in patterns of Congressional domination impended. ${ }^{46}$ But a tidal wave of money nevertheless rolled into the coffers of Gingrich, Gramm, Barbour, the three who made the 1994 revolution, with precisely the impact our model would predict. ${ }^{47}$

We suspect that similar cases exist, but detailed analyses of each cannot be easily or concisely done. Few other elections are so clear cut that published odds permit easy interpretation and the chances of getting lost in a thicket of particulars are high. It does not help that we disagree with many presuppositions that mainstream election analysts tend to take for granted. That literature largely fails to develop a realistic assessment of the actual incentive structures in Congress and takes occasional pronouncements from individual representatives about how they dislike fundraising altogether too seriously. We also suspect that political science rankings of "quality challengers" really index the attractiveness of candidates to donors in slightly disguised form. Nor do we find it at all odd that candidates running unopposed should nevertheless often collect millions of dollars in donations for reasons that go well beyond deterring challenges, though that is certainly one way money talks in the political system. We also believe that the process by which issues develop and affect campaigns is misunderstood and complicated by the fact that differences in the amounts of time and money devoted to them are hard to study.

Because a raft of arguments along these lines would take us too far afield, we think it is better to try to tackle the problem of reciprocal causality more broadly.

\footnotetext{
${ }^{46}$ The 1994 pattern is markedly different from 1990, the previous off year election.

${ }^{47}$ See "Postscript: The 1994 Explosion," in (Ferguson, 1995b). Early polls that year were not particularly promising for the Republicans, though after the money turned they improved substantially later in the campaign. By the end of the campaign, some, but not all, polls were showing a significant lead for the Republicans, which rather like the polls before Brexit in 2016, were not really believed, as the gambling odds testify. For a roundup of polls in 1994, see the roster in (Sherman, 2013). We have compared money coming in weekly during the campaign with the irregularly published Gallup polls. There is no question the money flow led the polls for most of the campaign. At the very end, after Gallup had switched to its likely voters samples, the polls caught up with the money, which is what should happen in a money-driven system. Here the case for some reciprocal causation is plausible.
} 
Figure 4

Iowa Market Predictions of House Control - 1994:

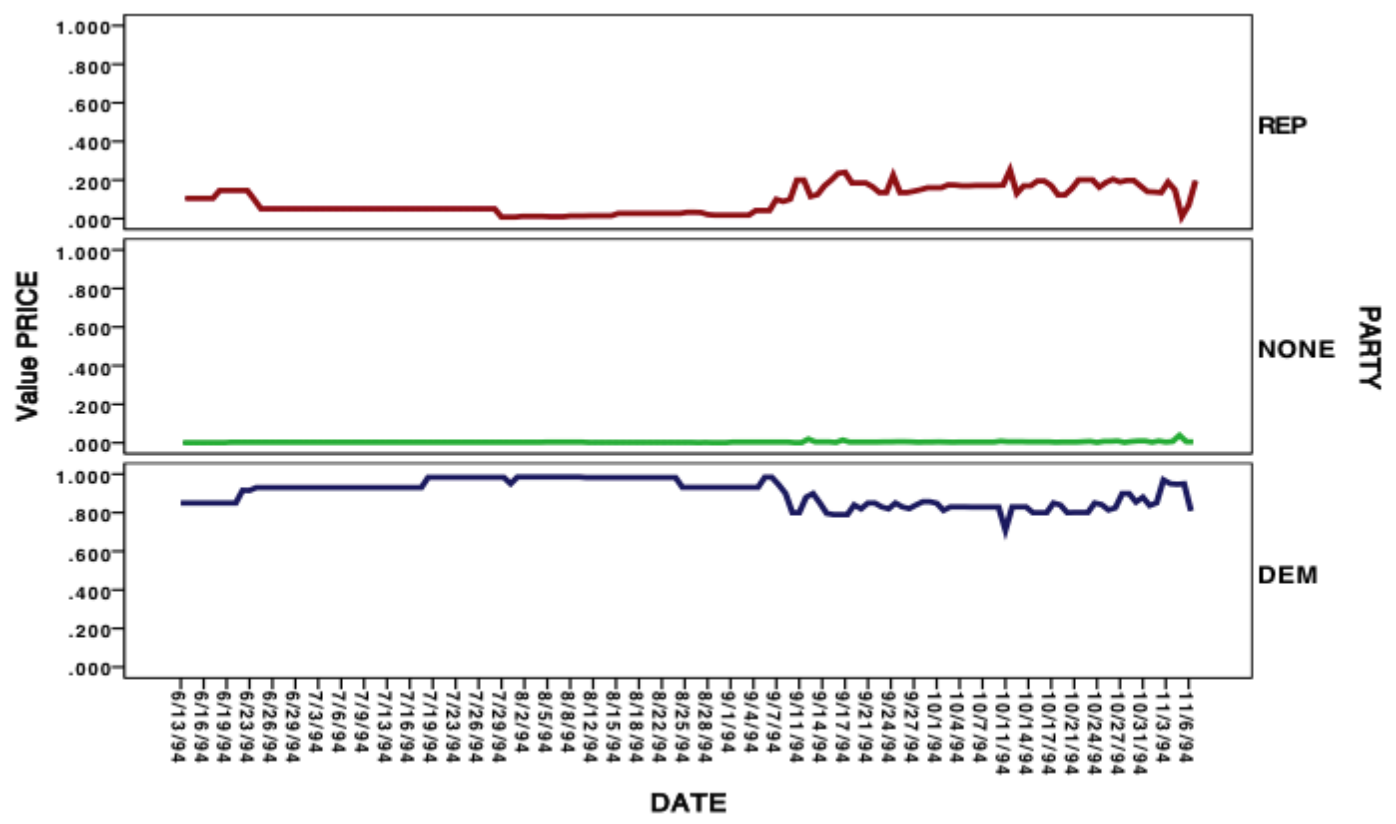


Figure 5

1994 Money Surge into Republican Campaign Coffers

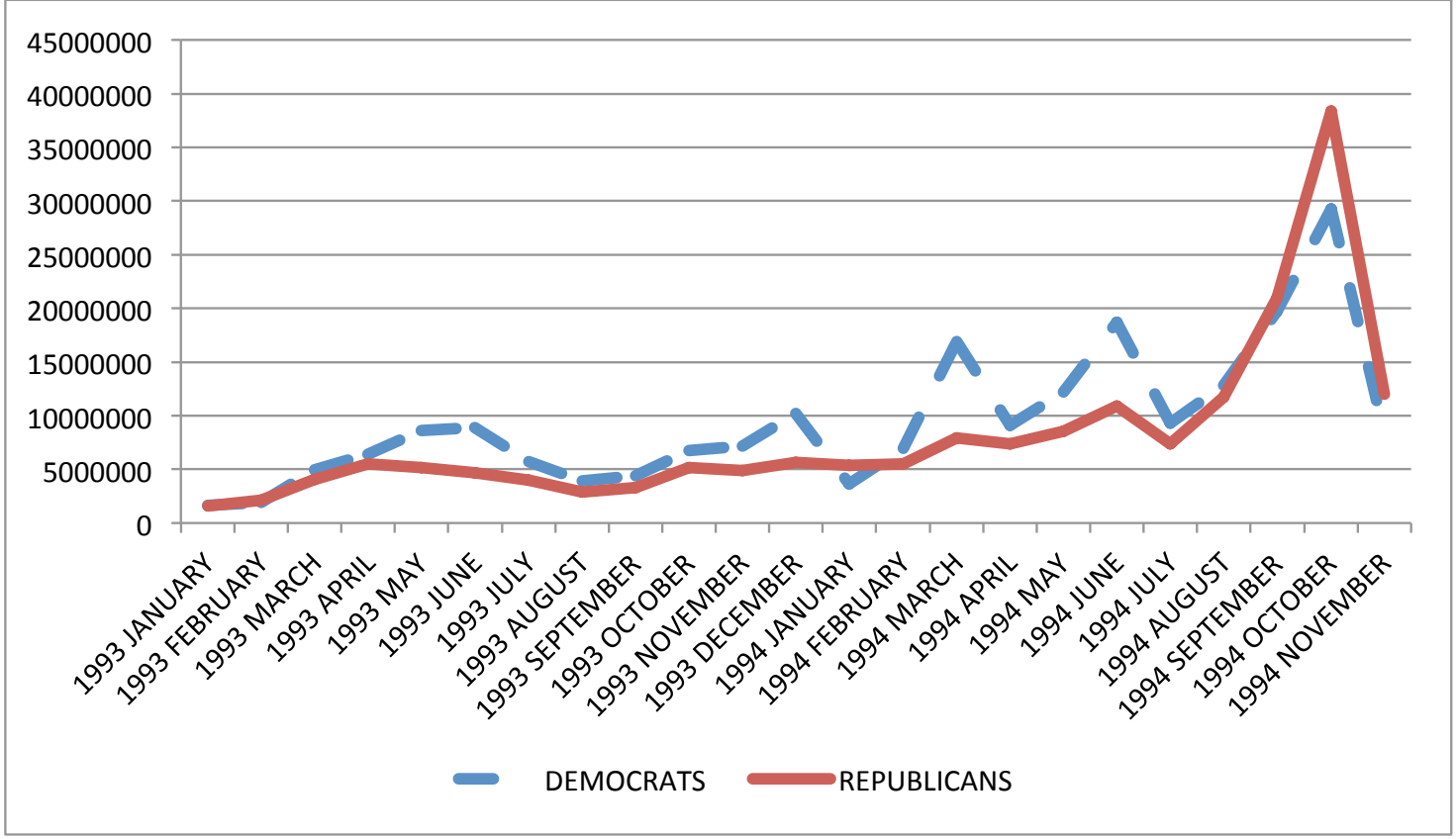

Total Reflects Totals for Congressional Campaign Committees, Party Committees, and All Other Identifiable Expenditures Including Soft Money and Independent Expenditures 
At first sight, the problem is daunting. Jacobson's review lucidly summarizes the results of a generation of such efforts.

The problem was recognized early on (Jacobson, 1978; Welch, 1981) but after nearly three decades of work there is no agreed-upon solution. The standard technical fix-up is to use a two-stage procedure, in which instrumental variables are "purged" of the effects of the reciprocally-related variables or of the component correlated with the omitted variables. The efficacy of this approach depends on finding exogenous variables that affect spending but not, directly, the vote (Johnston, 1972). This has proven difficult and the results remain inconclusive. Different choices of exogenous variables to identify the equations and compute the instruments produce a disconcerting variety of estimates of the relative effects of campaign spending by challengers and incumbents.

Reported results from various two-stage (sometimes three-stage) models of campaign spending effects range from repetition of the OLS findings in which challenger spending has a large effect while incumbent spending has no effect at all on the vote (Jacobson, 1978, 1980, 1985), to estimates suggesting that spending by incumbents is as least as productive as spending by challengers (Green and Krasno, 1988, 1990; Grier, 1991; Ansolabehere and Snyder, 1996; Gerber, 1998), with others falling in between (Bartels, 1991; Goidel and Gross, 1994). Alternative approaches produce an even broader range of results from evidence that neither candidate's spending matters much (Levitt, 1994) to evidence that the incumbent's spending may be equally or more productive than the challenger's spending (Goldstein and Freedman, 2000; Erikson and Palfrey, 1998), with others again taking the middle ground that incumbents do help themselves by spending money on campaigns, but with a lower marginal rate of return on their investment than challengers (BoxSteffensmeier, 1992; Kenny and McBurnett, 1997; Coates, 1994). ${ }^{48}$

As Jacobson indicates most efforts to resolve this problem rely on some instrumental variable, though a few researchers have tried other approaches, including Jacobson himself, who introduced a very interesting panel approach in the article containing this passage. The difficulty is that the technical requirements for instrumental variables are exigent; they need to be correlated with the original variable of interest, but not with the error in the new equation constructed using them. ${ }^{49}$ We are skeptical that much in this world is correlated with money that isn't money, to put matters somewhat baldly, and are not optimistic about finding that Snark. The abundance of sharply contrasting results only reinforces our skepticism.

We therefore searched for an approach that would make a virtue of ignorance and looked for methods relying on latent instrumental variables, that is, variables that are unknown to the

${ }^{48}$ (Jacobson, 2006).

${ }^{49}$ (Stock \& Watson, 2010). 
researchers. These exist; they have been developed by Ebbes and colleagues and used with apparent success in specialized applications in business and economics. ${ }^{50}$ Where their results have been compared with previous findings using more conventional approaches, such as the relations of earnings to schooling (where the latent variable is ability) they produce answers similar to previous studies. ${ }^{51}$

Much of our data, however, is spatially autocorrelated. Existing latent instrumental variable models usually rely on ordinary least squares for their estimation and thus require modification. We have developed a spatial latent instrumental variable model that we can estimate using Bayesian methods. Tables 1 and 2 present our results. Table 1 summarizes findings for the House; Table 2 for the Senate.

For all the House elections, the spatial latent instrumental variable model is needed; the data show significant spatial autocorrelation. By contrast, that pattern holds in fewer Senate elections. Where a spatial model is not necessary, we report results for a latent instrumental variable model relying on ordinary least squares. The coefficients for the political money term thus represent our best estimates of the true value of the way money drives elections. The basic finding, we think, is sobering: using the latent instrumental variable model usually reduces the coefficients on money compared to an ordinary least squares approach, but not by very much. They remain strong. Our conclusion, which we are the first to acknowledge needs more scrutiny, is that seeing should, after all, be believing: the case in favor of the proposition that money drives US elections is significantly strengthened. The endless arguments about cause and effect in money and politics, perhaps, are entering a new stage, with, we hope, the optics changed forever. We do not doubt that reverse causality happens, but the money flow should be regarded as powerful factor in its own right in election outcomes.

\section{Corporations Holding the Center?}

Our earlier work showed the strong dependence of both major parties on contributions from the very wealthiest Americans - the famous $1 \%$. As a result, we dismissed claims by both scholars and journalists regularly repeated in the heat of election contests that small donations

\footnotetext{
${ }^{50}$ See the references above.

${ }^{51}$ (Ebbes et al., 2005) and the discussion in (Hueter, 2016).
} 
are the bedrock of any but losing candidates' campaigns. The Sanders campaign has perhaps raised interesting new questions about this generalization, but it is too early to tell, and, after all, Sanders did not win, either, though we concede that his remarkable run brooks no comparison with the brief and abortive efforts mounted by poorly financed Republican Also Rans in 2012. ${ }^{52}$ We continue to believe that the ubiquity of big money makes it mandatory to look closely at money politics to understand major political changes, especially the political system's steady lurch to the right since the late nineteen sixties.

In our own work, we try to do exactly this. ${ }^{53}$ This research has made us suspicious of assertions that American corporations tend to the "political center." A full discussion of just how mistaken such views are requires more space than we have here. But we would like to close our discussion of the central role money plays in American politics with a simple demonstration of the fallacy of these assertions.

As indicated earlier, we doubt the validity of existing scales that purport to measure how far left or right major investors and corporations are in their political giving. But there are some distinctions that we accept as unproblematic. We certainly consider Tea Party Republicans to be a distinctive group with in the GOP and located well to the right of the rest of the party. A fortiori, as a group, they sit well to the right of the Democrats.

But that provides a simple test that is potentially very illuminating. If it is true, as often suggested, that Tea Party backers disproportionately represent eccentric billionaires rather than major American corporations, then rates of support for the Tea Party should be higher among the Forbes 400 than the rest of big business (defined as the largest 350 firms in the Fortune list and equivalently sized private firms not included on that list). Our data set allows us to test this directly for the 2012 election; it is an easy segmentation.

There are several ways to reckon support. One, which we continue to think is very illuminating, is simply to count the percentage of firms and investors making contributions. ${ }^{54} \mathrm{~A}$ second is to try to sum total contributions. But in the case of the Tea Party, for sure, the Dark

\footnotetext{
${ }^{52}$ (Ferguson et al., 2013); we repeat our caution, however, that we have not yet fully analyzed the Sanders data for the 2016 election cycle.

${ }^{53}$ (Ferguson, 1995b; Jones \& Jorgensen, 2012).

${ }^{54}$ See the discussion in (Ferguson et al., 2013) and (Ferguson, 1995b). Forbes members operating the same firm can obviously be counted as individuals or as a single investing unit. Here we do it both ways, for clarity.
} 
Money problem is acute - probably graver than for any other politically active groups. The evidence is strong that some famous investors have made extensive use of Dark Money to aid various people and organizations claiming the mantle. ${ }^{55}$ Their reported spending will thus appear far less than it is. Various court cases and investigative reports have also, however, brought to light various secret forms of spending by major corporations, in, for example, the health care industry, which have nothing to do with the Forbes list. ${ }^{56} \mathrm{We}$ thus consider all claims about total spending to be very unreliable; the percentage of firms contributing should be telling, however, since the Tea Party in 2012 was a known quantity.

Table 3 presents our results, which surprised even us. A simple count of firms and investors on Forbes show that the largest American corporations support Tea Party Congressional candidates and organizations supporting the movement, such as Freedom Works, at much higher rates than Forbes 400 members. ${ }^{57}$ Billionaires on the Forbes List, by contrast, contribute at substantially lower rates. Even making due allowances for Dark Money, the difference is substantial.

These results might be qualified in various ways, but their general point is clear: Stories that the steady rightward drift of the American political universe is somehow the work of exceptionally ideological individual entrepreneurs are huge over-simplifications. If the center is not holding in American society - and it rather plainly is not - America's largest companies are as implicated as anyone else; indeed, perhaps more so. ${ }^{58}$

Nevertheless, there is a striking regularity in our data that we are the first to admit perplexes us. In House elections, the coefficients in our Spatial Bayesian Latent Instrumental

\footnotetext{
${ }^{55}$ (Mayer, 2016); see also the discussion and references in (Ferguson, et al., 2013).

${ }^{56}$ See, again, (Ferguson et al., 2013). There is another reason for care about amounts: we err on the side of caution when aggregating spending to minimize the possibility that individuals or firms are reported as contributors when in fact they were not.

${ }^{57}$ This definition is different from the tests reported in (Ferguson et al., 2013) That used a narrower definition that excluded organizations like Freedom Works in favor of support for candidates' campaign and leadership committees. Of course it, too, showed important support for the Tea Party from major American companies, as we said plainly. Note that our test does not count contributions given indirectly by companies through vehicles like the U.S. Chamber of Commerce. We focus on direct contributions coming from executives, the company itself, or its political action committees in the full range of ways earlier discussed.

${ }^{58}$ Note that Tea Party candidates shared the extreme hostility of banks to the admittedly half hearted regulatory efforts mounted by the Obama administration. They thus were natural vehicles for financiers looking for allies in a pinch, as the case of Scott Brown in Massachusetts could have told anyone who bothered to look. See (Ferguson and Chen, 2010).
} 
Table 3

Big Business Firms Support Tea Party Candidates at Substantially Higher Rates than Members of the Forbes 400

( $\mathrm{N}=773$, Forbes 380 "Investing Units," Big Business 393)

(Forbes Individuals $=396$ )

Big Business and Forbes 400 Members Combined - 51\%

Big Business Without Forbes 400 - 79\%

$\$ 16,751,500$

$(\mathrm{N}=310$ out of 393)

Forbes 400 Members $-23 \%$

$\$ 13,818,233$ *

( $\mathrm{N}=92$ out of 396, or 380)

$* \$ 12,457,400$ of which is from one investor; nothing comparable for Big Business; but see text caution about Dark Money totals on both sides.

Investing Units $=$ Counts Forbes members in same firms as one unit. 
Variable models represent our best efforts to estimate the strength of money in each year. A close look suggests there is a time trend in the coefficients for elections in the House. They drop slightly, but steadily, from 1980 to 2014, which implies that, for example, a one percent increase in the Democratic share of total two party money has led over time to slightly lower increases in the Democratic vote share.

We are intrigued by this finding, but are agnostic about its cause. Senate elections do not display this pattern. Given that it holds only for the House, one might conjecture that it may be related to redistricting. But we are not persuaded that the evidence for this is clear cut. Here we have space only to note the pattern and the puzzle and dismiss any implication that big money's role in the system is declining in any serious sense - the drop is quite small in absolute terms. The coefficients for money remain very high. If the trend continued for another generation, they would still be very strong; the very evidence suggesting limited decline in fact testifies that money remains a giant factor in House elections.

\section{Conclusion: Recognizing A Money-Driven Political System}

In the last generation the center of gravity of American politics has shifted dramatically. Income inequality has soared and the system has become so dysfunctional that even many affluent voters are in revolt, as racial and ethnic cleavages are intensified by economic breakdown. ${ }^{59}$ Statistical studies of the subset of public policies that have drawn enough long term attention from pollsters to permit tests show that ordinary Americans have essentially no influence on public policy when their preferences run counter to those of the rich. ${ }^{60}$ The few direct studies of opinions of the super-rich also show they are far more conservative on most economic issues than the rest of the population. Not surprisingly, when economists compare actual public policies with those that would benefit average Americans they now often summarily reject older "median voter" approaches to understanding politics. ${ }^{61}$ They thus close ranks with most Americans, who have long since drawn that conclusion.

\footnotetext{
${ }^{59}$ As witness the Trump and Sanders candidacies in the 2016 election.

${ }^{60}$ (Gilens, 2012); (Gilens \& Page, 2014).

${ }^{61}$ See, e.g., (Sachs, 2013).
} 
Figure 6

Decline in Effectiveness of Money in House Races:

The Testimony of SBLIV Model Coefficients

1980 - 2014 House Data

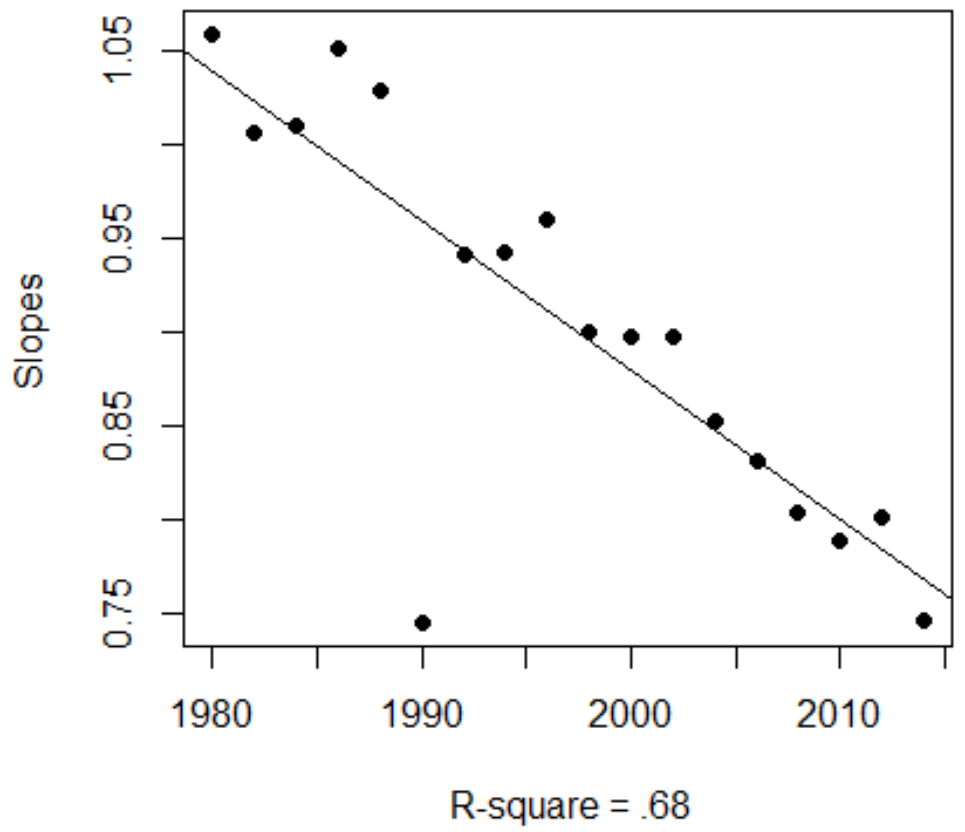


We think it is time that social scientists stop pushing the equivalent of the Ptolemaic solar system and recognize what everyone else does: that we live in a money-driven political system. We are the first to admit that our paper employs a new approach to treating the instrumental variable problem. But we are able to check its conclusions by an entirely different method that is now routine within economics and finance. We think at a minimum our results should shift the burden of proof and for sure the evidence we have amassed should change the optics of the whole discussion: the association on its face of money and election outcomes is very strong. In one offs, such as presidential elections, the pattern may be harder to see, but where cases are numerous, the association becomes visible immediately, if researchers will only take the trouble to look.

It goes without saying that this news is not reassuring; particularly in elections below the federal level - in states and local elections, we suspect, money has come to dominate outcomes to a frightening degree, not least because it is unlikely that the Republican advantage is offset there to the degree that it has been in recent federal elections. ${ }^{62}$ If it turns out that the US has entered a Post-Democratic age, the situation will not be improved by social scientists behaving like ostriches. It is time economics, political science, and history recognize the reality of industrial and financial blocs within parties and acknowledge money's powerful effects on elections.

\footnotetext{
${ }^{62}$ A senior political consultant observes to us that our results imply that the number of potentially contestable elections is markedly wider than commonly supposed.
} 


\section{Appendix I: A Note on Methods}

This paper relies on much new data compiled from the Federal Election Commission and the U.S. Internal Revenue Service and employs a variety of statistical models to analyze these. We discuss this data at some length in our main text and more formally in Appendix 2. This Appendix presents our statistical models in detail. We specify full, formal models, in what we hope is an accessible fashion.

Our main models concern House districts and states with elections for the Senate. These all occupy definite areas in space, with some adjacent to each other. This poses a potential problem for statistical analysis, because the strong resemblances between neighboring areas mean that all those observations may not in fact be independent in a statistical sense; they might contain less information than a set of independent observations would. This spatial autocorrelation, rather like the better known case of temporal autocorrelation, can distort statistical estimates.

Though many studies of Congressional elections do not bother to test for the presence of spatial autocorrelation, we think this is a bad procedure. Often it is true, the differences between spatial regressions and ordinary least squares (OLS) are not huge, but this needs to be shown, not assumed.

In our previous work on Congress, we have tested for the presence of spatial autocorrelation, typically by running Moran I tests (Cliff \& Ord, 1981; Moran, 1950). This time, as usual, both map plots of the dependent variable of the percentage of Democratic votes as well as the residuals of the Ordinary Least Squares (OLS) regressions often showed clear signs of spatial autocorrelation.

This spatial autocorrelation complicates our treatment of endogeneity in the independent variables. As we outline in the text, our paper tackles this classic problem head on by developing the latent instrumental variable (LIV) analysis proposed by Ebbes and his coworkers. The method has been used by some researchers, but it is not yet widely appreciated in political science, economics, or sociology. Irene Hueter's comprehensive review of the LIV (including an earlier version of this paper) method should help greatly to make it more widely understood. ${ }^{63}$

We cannot hope to substitute for her much more detailed treatment, but we want to clearly specify what we did in our paper. We follow Ebbes' lead to develop a spatial regression model with Latent Instrumental Variables using a Bayesian approach. ${ }^{64}$ This spatial Bayesian latent instrumental variable (SBLIV) method, in contrast to the usual way of tackling

\footnotetext{
63 (Hueter, 2016).

${ }^{64} \mathrm{Cf}$. Hueter on some advantages of using a Bayesian approach in settings like ours and the discussion of Ebbes and colleagues in the text.
} 
endogeneity, does not require the availability of "external" instrumental variables and takes account of spatial dependencies that exist between adjacent observations.

Formally, let $Y_{i}, i=1, \cdots, N$, (where $\mathrm{N}$ is the number of districts) be the dependent variable, which is the difference between the Democratic and Republican vote as a percent of all votes for the two major parties, and $X_{i}$ be the endogenous regressor, which is money favoring Democrats as a percent of all money spent on or by the two major parties. ${ }^{65}$ Then the SBLIV model is defined as the following:

$$
\begin{gathered}
Y_{i}=\beta_{0}+\beta_{1} X_{i}+b_{i}+\varepsilon_{i} \\
X_{i}=\theta_{i}+v_{i} \\
b_{i} \mid b_{j \neq i} \sim N\left(\bar{b}_{i}, \sigma_{b}^{2} / m_{i}\right)
\end{gathered}
$$

where $b_{i}$ captures district clustering via a Conditional Autoregressive (CAR) model, $\bar{b}_{i}=\frac{1}{m_{i}} \sum_{j \neq i}^{n} b_{j}, m_{i}$ is the number of neighbors of district $i$, with $b_{j}=1$, if $j$ and $i$ are neighbors and 0 otherwise. $X_{i}$, the independent variable, is split into an exogenous part $\theta_{i}$ and an endogenous part $v_{i}$ where $v_{i}$ is assumed to have a mean of zero and a variance $\sigma_{v}^{2}$. The error terms $\varepsilon_{i}$ are independently and identically distributed across districts with zero mean and variance $\sigma_{\varepsilon}^{2}$. It is also assumed that $v_{i}$ and $\varepsilon_{i}$ are correlated with the covariance matrix as:

$$
\Sigma=\left[\begin{array}{ll}
\sigma_{v}^{2} & \sigma_{\varepsilon v} \\
\sigma_{\varepsilon v} & \sigma_{\varepsilon}^{2}
\end{array}\right] .
$$

We follow the same approach as in (Ebbes, Boechenholt, Wedel, \& Nam, 2009) to assume there is linear projection between the structural error $\varepsilon_{i}$ and the reduced form error $v_{i}$ as:

$$
\varepsilon_{i}=\rho_{i} v_{i}+u_{i}
$$

So Equation (1) is reduced to:

$$
Y_{i}=\beta_{0}+\beta_{1} X_{i}+b_{i}+\rho_{i} v_{\mathrm{i}}+u_{i}
$$

\footnotetext{
${ }^{65}$ In symbols, the dependent variable is [\% Dem Vote - \% Rep Vote] / [Total Dem plus Rep Vote]), which as the text indicates will be negative when Democrats lose the election. The endogenous regressor $\mathrm{X}_{\mathrm{i}}$, the money variable is [All Money Favoring Dems] / [All Money Favoring Dem + All Money Favoring Rep]). If money was spent against the Republican, then that would go in the Favoring Dem category and vice versa.
} 
where $\rho=E\left(\varepsilon_{i} v_{i}\right) / E\left(v_{i}^{2}\right)$, and $E\left(v_{i} u_{i}\right)=0$. The covariate $X_{i}$ is endogenous when $E\left[\varepsilon_{i} v_{i}\right] \neq 0$, in which case traditional inferential techniques are biased and inconsistent. If $\theta_{i}$ is observed as in the standard IV case, the estimators are unbiased and consistent. However, if the observed instrumental variables are poor proxies for the instrument $\theta_{i}$, they exhibit a poor correlation that results in dependency between $\theta_{i}$ and $\varepsilon_{i}$.

Ebbes' method has not yet been extended to include continuous endogenous variables. Instead his method slices the endogenous variable into a set of categories; the approach, as Hueter explains, is not very sensitive to the precise number researchers employ. In simulations we have experimented with various numbers of categories, but get essentially the same results.

In the above equation, $\theta_{i}$ is the unobserved instrumental variable with $L$ support points $\pi_{1}, \cdots, \pi_{L}$ that define the categories with probabilities $\lambda_{1}, \cdots, \lambda_{L}$ where each $\pi_{l} ; l=1: L$ has a normal prior with mean $a_{l}$ and precision parameter $\tau_{l}, \pi_{l} \sim N\left(a_{l}, \tau_{l}\right)$, and each $\lambda_{l}$ has a Dirichlet prior $\lambda \sim \operatorname{Dirichlet}(\boldsymbol{\alpha})$. (The Dirichet prior is necessary because of the categorical form.) From Ebbes (2005) Equation (7.10) it can be seen that the full conditional posterior distribution of $\theta_{i}$ is a mixture of a normal distribution and a discrete distribution with weights on the distinct values according to the probability of $\lambda$. For example of $L=4$,

$$
\theta_{i} \sim \lambda_{1} \pi_{1}+\lambda_{2} \pi_{2}+\lambda_{3} \pi_{3}+\lambda_{4} \pi_{4}
$$

will be estimated from the data using a Bayesian approach with standard, conjugate priors for $\beta_{0}$, $\beta_{1}$, and $\rho$,

$$
\beta_{0}, \beta_{1} \text { and } \rho \sim N(0,1 / 1000) \text {. }
$$

We are sometimes asked about the implied estimates of the latent instrumental variable. ${ }^{66}$ In Bayesian terms the question concerns the estimated posterior distribution for the latent instrumental variables. In this Appendix we present below estimates for House data for 1980, 1986, and 2012; other years look quite similar.

\footnotetext{
${ }^{66}$ In our case, there is one quite obvious candidate variable - some measure of the candidate's popularity with voters; but note Hueter's discussion on the relative insensitivity of the number of instrumental variables.
} 


\section{Appendix Figure 1}

1980 House data, 4 clusters of LIV. LIV $\sim$ Mixture Normal with $\lambda=(.012, .025, .081, .882)$ and

LIV .012N $(.134, .028)+.025(.261, .034)+.081 N(.382, .032)+.882(.490, .020)$

Histogram of the Mixture Model for LIV 1980 data, $\mathrm{N}=382$

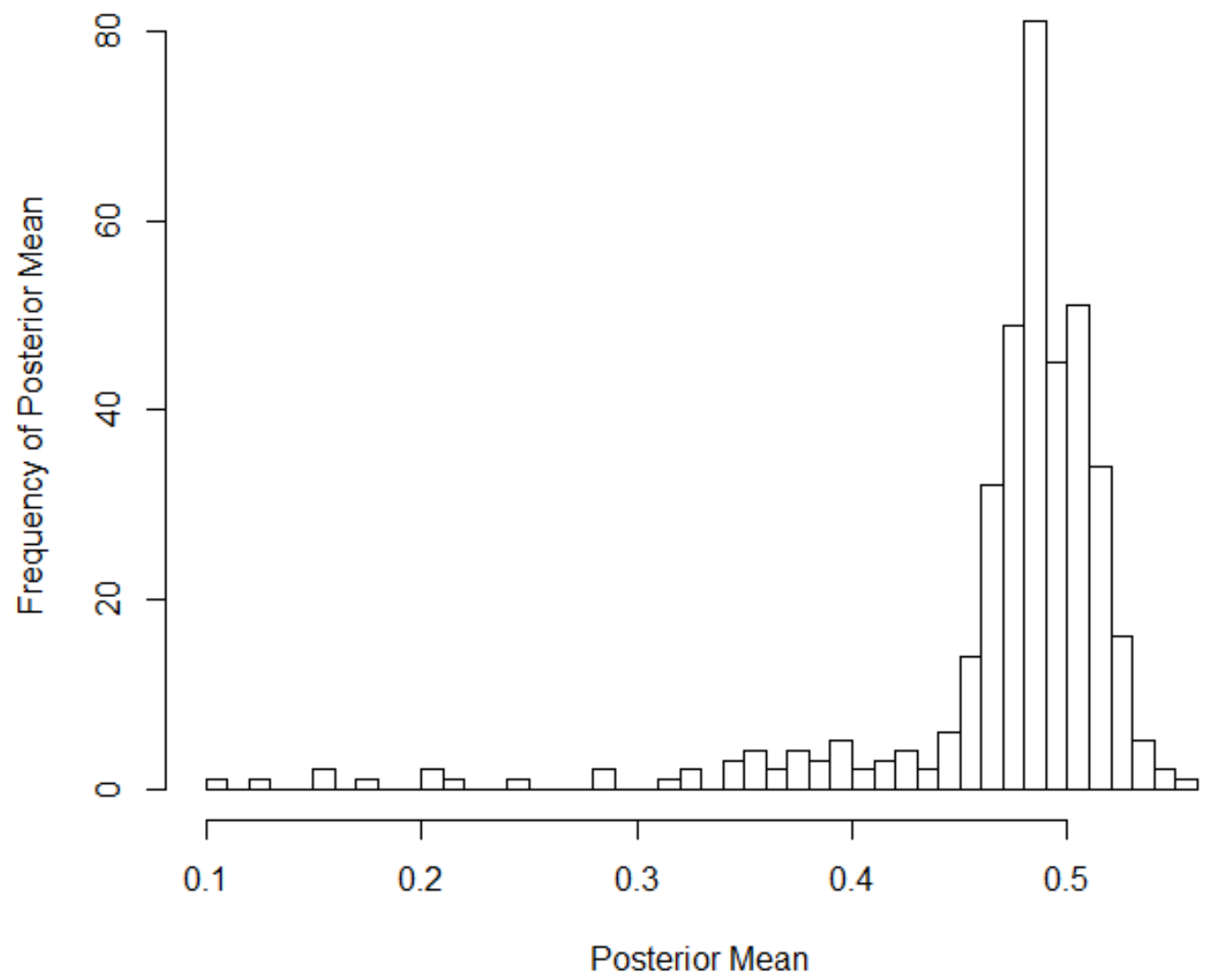


Appendix Figure 2:

1986 House data, 4 clusters of LIV. LIV $\sim$ Mixture Normal with $\lambda=(.017, .032, .072, .878)$ and

LIV .017N $(.135, .028)+.032(.265, .034)+.072 N(.390, .033)+.878(.506, .022)$

Histogram of the Mixture Model for LIV 1986 data, $\mathrm{N}=361$

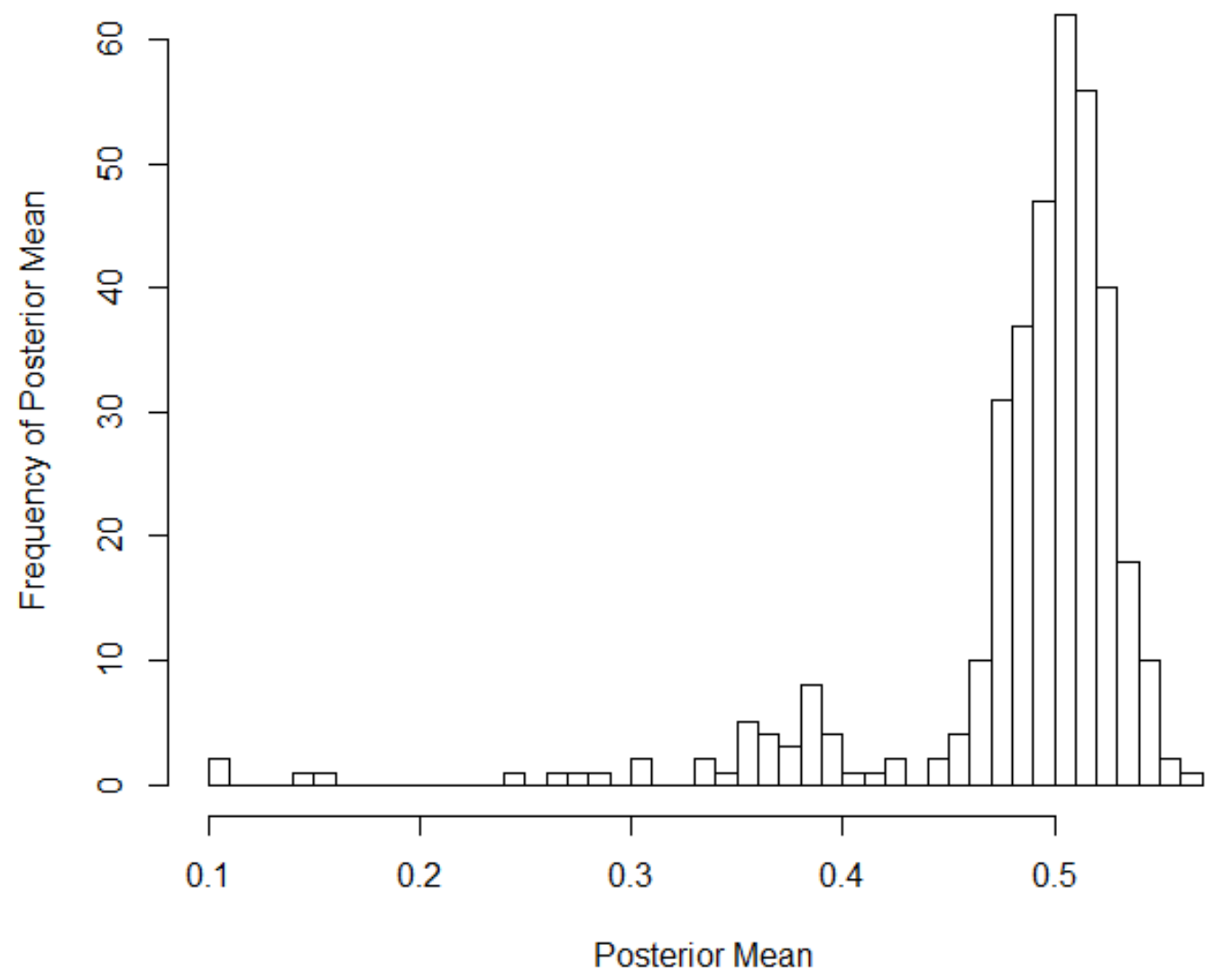


Appendix Figure 3:

2012 House data, 4 clusters of LIV. LIV $\sim$ Mixture Normal with $\lambda=(.010, .016, .161, .813)$ and

LIV .010N(.125,.029) + .016(.246,.038) $+.161 N(.359, .037)+.813(.431, .022)$

Histogram of the Mixture Model for LIV 2012 data, N = 384

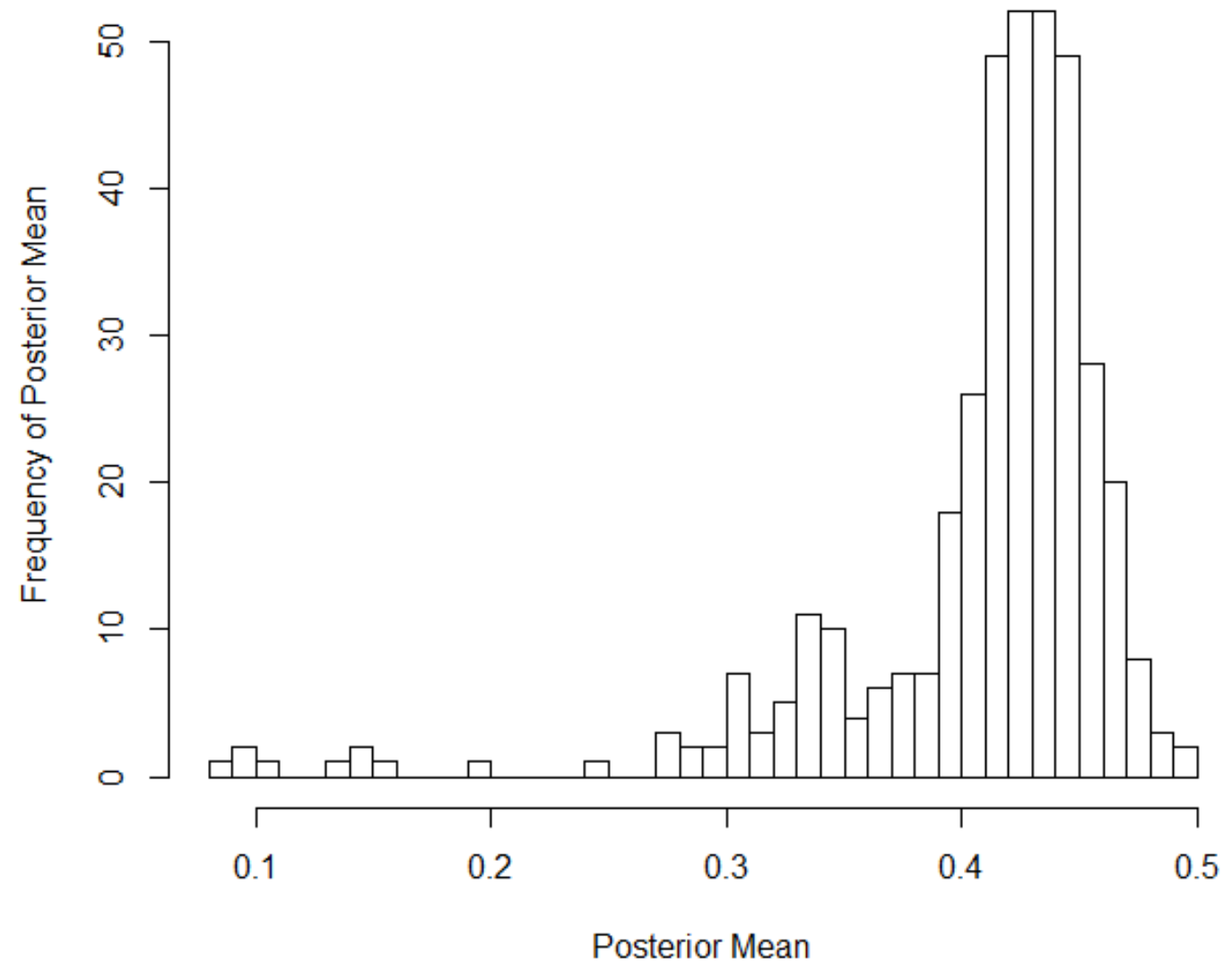




\section{Appendix 2: Campaign Finance Data Sources and Documentation for Linear Model}

\section{Campaign Finance Data Sources}

1. Federal Election Commission: $1980-2014$
a. ftp://ftp.fec.gov/
b. www.fec.gov/portal/download.shtml

\section{Variable Selection}

Our goal is to capture all known spending for and against the candidates in our sample of races for the U.S. House of Representatives and the U.S. Senate from 1980 to 2014. The type of spending reported to the Federal Election Commission (FEC), and how the FEC discloses this spending changes during those years. The types of spending we use include: total candidate disbursements, total party coordinated expenditures, total independent expenditures for and against, total communication costs for and against, total non-party independent expenditures for and against, total party independent expenditures for and against, and total known electioneering communications for and against the candidates in our sample. The FEC's description of these types of spending is as follows:

1. CANDIDATE TOTAL DISBURSEMENTS: "This column includes all outgoing funds reported by all authorized committees on Line 22 . It does not include disbursements by office-account committees, or joint fund-raising committees."

2. PARTY COORDINATED EXPENDITURES: "These expenditures are permitted in 2 U.S.C. Section $441 \mathrm{a}(\mathrm{d})$, and are reported on Line 23 of Schedule F of FEC Form 3x, filed by the party committee. Limits on these expenditures are based on voting age population of the state for Senate candidates, and were fixed at $\$ 30,910$ for House campaigns in 2004."

3. INDEPENDENT EXPENDITURES: "This figure represents the total amount of independent expenditures made by filers other than political committees to advocate the election (or defeat) of the candidate. Independent expenditures are not made with the cooperation of, or in consultation with, the candidate or his or her agents or authorizing committees. The source is FEC Form 5 filed by the person making the expenditure."

4. COMMUNICATION COSTS: "This column shows the total amount of treasury funds reported by corporations, labor unions, and other membership organizations to make internal communications which advocate the election (or defeat) of the candidate. These communications may be made only to certain categories of individuals (stockholders and executives and administrative personnel of the corporations, members of the unions and membership organizations.) The organization is not required to report these expenditures to the Commission on FEC Form 7 until they exceed \$2,000 per election for all candidates. Thereafter, all additional communication costs must be reported."

5. NON-PARTY INDEPENDENT EXPENDITURES: "This figure represents the total amount of independent expenditures made by non-party committees to advocate the election (or defeat) of the candidate. Independent expenditures are not made with the 
cooperation of, or in consultation with, the candidate or his or her agents or authorizing committees. The source is Schedule E supporting Line 22."

6. PARTY INDEPENDENT EXPENDITURES: "These independent expenditures made by party committees advocating the election (or defeat) of the candidate. They were permitted in 1996 for the first time as a result of the Supreme Court ruling in FEC v Colorado Republican Party."

7. ELECTIONEERING COMMUNICATIONS: "An electioneering communication is any broadcast, cable or satellite communication that fulfills each of the following conditions: 1. The communication refers to a clearly identified candidate for federal office; 2 . The communication is publicly distributed shortly before an election for the office the candidate is seeking; and 3. The communication is targeted to the relevant electorate (U.S. House and Senate candidates only)." "A communication refers to a clearly identified federal candidate if it contains the candidate's name, nickname or image, or makes any unambiguous reference to the person or their status as a candidate, such as 'the Democratic candidate for Senate,'... The electioneering communication rules apply only to communications that are transmitted within 60 days prior to a general election or 30 days prior to a primary election."

To obtain all of this spending, we must use both the FEC's Summary Files and its Detailed or Itemized Files. The summary file for candidates, used from 1980 to 2006 is called CANSUM. The CANSUM file included sum totals for each candidate regarding: candidate disbursements, party coordinate expenditures, independent expenditures for and against, communication costs for and against, non-party independent expenditures for and against, and party independent expenditures for and against. We accessed the CANSUM files for 1980 through 2006 here: $\mathrm{ftp}: / / \mathrm{ftp}$. fec.gov/.

Starting with the 2008 election cycle, the FEC moved to what it calls the DATA CATALOG. The candidate summary file in the DATA CATALOG does not contain all of the various types of spending external to the candidate that was found in CANSUM; instead, the DATA CATALOG only contains total candidate disbursements. We use the candidate summary file in the DATA CATALOG to measure total candidate disbursements for 2008 through 2014. We accessed the candidate summary file in the DATA CATALOG here:

http://www.fec.gov/data/DataCatalog.do? format=html. To obtain the totals per candidate for party coordinated expenditures, independent expenditures for and against, and communication costs for and against, we use the FEC's Detailed or Itemized Files, specifically its ITCONT and ITOTH files. We aggregated those spending categories out of those files per candidate. We accessed the ITCONT and ITOTH files here: http://www.fec.gov/finance/disclosure/ftpdet.shtml.

To complicate matters, the FEC added recently a WEBALL file, with a column for total candidate disbursements. The FEC's description of this file is as follows: "The all candidate 
summary file contains one record including summary financial information for all candidates who raised or spent money during the period no matter when they are up for election. This file is similar to the current campaign summary file described above. This file is completely dependent upon summary information reported by the campaign itself." We accessed the WEBALL file here: http:/www.fec.gov/finance/disclosure/ftpsum.shtml. However, the FEC produced a WEBALL file going back to 1980, so that for all years, 1980 through 2014 there is a WEBALL file to compete with a CANSUM and DATA CATALOG file. We accessed the WEBALL files going back to 1980 here: ftp://ftp.fec.gov/. Much to our surprise, the total disbursement column in these files differs somewhat from that in the DATA CATALOG or the CANSUM file for the same candidates. After contacting the FEC over the discrepancy between WEBALL, DATA CATALOG, and CANSUM, our conclusion is that none of these datasets have an obvious claim to better describe the reality of total candidate disbursements. The discrepancies between them are nearly always minute. We checked to see how the results of our model change if one uses the WEBALL data instead; the answer was that the fit changed minutely. We accordingly have gone ahead and used the data described above; we do not believe any substantial differences will turn up, no matter which data set one relies on.

In what follows is a list of our spending variables and where/how we obtained these variables for each election cycle, 1980 through 2014:

1. DEM_DISBURSE: Total Disbursements By The Democratic Candidate, Available For $1980-2014$

a. 1980 - 1982: CANSUM Column 11, Counting Filler Columns

b. 1984 - 2006: CANSUM Column 8

c. 2008 - 2014: DATA CATALOG Column 42, 'tot_dis'

d. 1980 - 2014: WEBALL Column 8, 'TTL_DISB'

2. REP_DISBURSE: Total Disbursements By The Republican Candidate, Available For $1980-2014$

a. 1980 - 1982: CANSUM Column 11, Counting Filler Columns

b. 1984 - 2006: CANSUM Column 8

c. 2008 - 2014: DATA CATALOG Column 'tot dis' 1980 - 2014: WEBALL Column 8, 'TTL_DISB'

3. DEM_PCE: Party Coordinated Expenditures For The Democratic Candidate, Available For $1980-2014$

a. 1980 - 1982: CANSUM Column 24, Counting Filler Columns

b. 1984 - 1994: CANSUM Column 26

c. 1996 - 2006: CANSUM Column 47

d. 2008 - 2014: ITOTH \&/or ITCONT Column 6, 'TRANSACTION_TP', '24C'

4. REP_PCE: Party Coordinated Expenditures For The Republican Candidate, Available For $1980-2014$

a. 1980 - 1982: CANSUM Column 24, Counting Filler Columns

b. 1984 - 1994: CANSUM Column 26 
c. 1996 - 2006: CANSUM Column 47

d. 2008 - 2014: ITOTH \&/or ITCONT Column 6, 'TRANSACTION_TP', '24C'

5. DEM_IE_FOR: Independent Expenditure For The Democratic Candidate, Available For $1980-2014$

a. 1980 - 1982: CANSUM Column 31, Counting Filler Columns

b. 1984 - 2006: CANSUM Column 35

c. 2008 - 2014: ITOTH \&/or ITCONT Column 6, 'TRANSACTION_TP', '24E'

6. DEM_IE_AGAINST: Independent Expenditure Against The Democratic $\bar{C}$ andidate, Available For 1980 - 2014

a. 1980 - 1982: CANSUM Column 44, Counting Filler Columns

b. 1984 - 2006: CANSUM Column 36

c. 2008 - 2014: ITOTH \&/or ITCONT Column 6, 'TRANSACTION_TP', '24A'

7. REP IE FOR: Independent Expenditure For The Republican Candidate, Available For $1980-2014$

a. 1980 - 1982: CANSUM Column 31, Counting Filler Columns

b. 1984 - 2006: CANSUM Column 35

c. 2008 - 2014: ITOTH \&/or ITCONT Column 6, 'TRANSACTION_TP', '24E'

8. REP_IE_AGAINST: Independent Expenditure Against The Republican Candidate, Available For 1980 - 2014

a. 1980 - 1982: CANSUM Column 44, Counting Filler Columns

b. 1984 - 2006: CANSUM Column 36

c. 2008 - 2014: ITOTH \&/or ITCONT Column 6, 'TRANSACTION_TP', '24A'

9. DEM_CC_FOR: Communication Cost For The Democratic Candidate, Available For $1980-201 \overline{4}$

a. 1980 - 1982: CANSUM Column 32, Counting Filler Columns

b. 1984 - 2006: CANSUM Column 37

c. 2008 - 2014: ITOTH \&/or ITCONT Column 6, 'TRANSACTION_TP', '24F'

10. DEM_CC_AGAINST: Communication Cost Against The Democratic Candidate, Available For 1980 - 2014

a. 1980 - 1982: CANSUM Column 45, Counting Filler Columns

b. 1984 - 2006: CANSUM Column 38

c. 2008 - 2014: ITOTH \&/or ITCONT Column 6, 'TRANSACTION_TP', '24N'

11. REP_CC_FOR: Communication Cost For The Republican Candidate, Available For 1980 $-2014$

a. 1980 - 1982: CANSUM Column 32, Counting Filler Columns

b. 1984 - 2006: CANSUM Column 37

c. 2008 - 2014: ITOTH \&/or ITCONT Column 6, 'TRANSACTION_TP', '24F'

12. REP_CC_AGAINST: Communication Cost Against The Republican Candidate, Available For 1980 - 2014

a. 1980 - 1982: CANSUM Column 45, Counting Filler Columns

b. 1984 - 2006: CANSUM Column 38

c. 2008 - 2014: ITOTH \&/or ITCONT Column 6, 'TRANSACTION_TP', '24N'

13. DEM_NP_IE_FOR: Non-Party Independent Expenditure For The Democratic Candidate, Available For 1980 - 2006

a. 1980 - 1982: CANSUM Column 42, Counting Filler Columns

b. 1984 - 2006: CANSUM Column 33 
c. 2008 - 2014: Included in DEM_IE_FOR

14. DEM_NP_IE_AGAINST: Non-Party Independent Expenditure Against The Democratic Candidate, Available For 1980 - 2006

a. 1980 - 1982: CANSUM Column 43, Counting Filler Columns

b. 1984 - 2006: CANSUM Column 34

c. 2008 - 2014: Included in DEM_IE_AGAINST

15. REP_NP_IE_FOR: Non-Party Independent Expenditure For The Republican Candidate, Available For 1980 - 2006

a. 1980 - 1982: CANSUM Column 42, Counting Filler Columns

b. 1984 - 2006: CANSUM Column 33

c. 2008 - 2014: Included in REP_IE_FOR

16. REP_NP_IE_AGAINST: Non-Party Independent Expenditure Against The Republican Candidate, Available For 1980 - 2006

a. 1980 - 1982: CANSUM Column 43, Counting Filler Columns

b. 1984 - 2006: CANSUM Column 34

c. 2008 - 2014: Included in REP_IE_AGAINST

17. DEM_PARTY_IE_FOR: Party Independent Expenditures For The Democratic Candidate, Available For 1996 - 2006

a. 1996 - 2006: CANSUM Column 26

b. 2008 - 2014: Included in DEM_IE_FOR

18. DEM_PARTY_IE_AGAINST: Party Independent Expenditures Against The Democratic Candidate, Available For 1996 - 2006

a. 1996 - 2006: CANSUM Column 48

b. 2008 - 2014: Included in DEM_IE_AGAINST

19. REP_PARTY_IE_FOR: Party Independent Expenditures For The Republican Candidate, Available For $\overline{1996}-2006$

a. 1996 - 2006: CANSUM Column 26

b. 2008 - 2014: Included in REP IE_FOR

20. REP_PARTY_IE_AGAINST: Party Independent Expenditures Against The Republican Candidate, Available For 1996 - 2006

a. 1996 - 2006: CANSUM Column 48

b. 2008 - 2014: Included in REP_IE_AGAINST

21. DEM_ELECTIONEERING_FOR: Electioneering Communications For The Democratic Candidate, Available For $2004-2014$

a. The committees engaging in electioneering communications have an identification number assigned by the FEC starting with ' $\mathrm{C} 3$ ' and do not have to identify a specific candidate they are supporting or opposing with their electioneering communications; however, some of these ' $\mathrm{C} 3$ ' committees do identify a candidate. In these instances, we researched the origin and purpose of these committees in order to understand whether they supported or opposed the candidate in question. After the Supreme Court's decision in Citizens United v FEC (2010), the amount of electioneering communications decreased and may not be present in some of these later datasets. We obtained the dollar value from ITOTH \&/or ITCONT Column 6, 'TRANSACTION_TP', '29'.

22. DEM_ELECTIONEERING_AGAINST: Electioneering Communications Against The Democratic Candidate, Available For 2004 - 2014 
a. The committees engaging in electioneering communications have an identification number assigned by the FEC starting with ' $\mathrm{C} 3$ ' and do not have to identify a specific candidate they are supporting or opposing with their electioneering communications; however, some of these ' $\mathrm{C} 3$ ' committees do identify a candidate. In these instances, we researched the origin and purpose of these committees in order to understand whether they supported or opposed the candidate in question. After the Supreme Court's decision in Citizens United v FEC (2010), the amount of electioneering communications decreased and may not be present in some of these later datasets. We obtained the dollar value from ITOTH \&/or ITCONT Column 6, 'TRANSACTION_TP', '29'.

23. REP_ELECTIONEERING_FOR: Electioneering Communications For The Republican Candidate, Available For $2004-2014$

a. The committees engaging in electioneering communications have an identification number assigned by the FEC starting with ' $\mathrm{C} 3$ ' and do not have to identify a specific candidate they are supporting or opposing with their electioneering communications; however, some of these 'C 3 ' committees do identify a candidate. In these instances, we researched the origin and purpose of these committees in order to understand whether they supported or opposed the candidate in question. After the Supreme Court's decision in Citizens United v FEC (2010), the amount of electioneering communications decreased and may not be present in some of these later datasets. We obtained the dollar value from ITOTH \&/or ITCONT Column 6, 'TRANSACTION_TP', '29'.

24. REP_ELECTIONEERING_AGAINST: Electioneering Communications Against The Republican Candidate, Available For 2004 - 2014

a. The committees engaging in electioneering communications have an identification number assigned by the FEC starting with ' $\mathrm{C} 3$ ' and do not have to identify a specific candidate they are supporting or opposing with their electioneering communications; however, some of these ' $\mathrm{C} 3$ ' committees do identify a candidate. In these instances, we researched the origin and purpose of these committees in order to understand whether they supported or opposed the candidate in question. After the Supreme Court's decision in Citizens United v FEC (2010), the amount of electioneering communications decreased and may not be present in some of these later datasets. We obtained the dollar value from ITOTH \&/or ITCONT Column 6, 'TRANSACTION_TP', '29'.

Using these spending variables we construct a variable called DEM_PERCENT_MONEY. This variable is calculated using this formula:

[(DEM_TOTAL_MONEY_FOR + REP_TOTAL_MONEY_AGAINST)

(DEM_TOTAL_MONEY_FOR + DEM_TOTAL_MONEY_AGAINST +

REP_TOTAL_MONEY_FOR + REP_TOTAL_MONEY_AGAINST)] 
DEM_PERCENT_MONEY is the total favorable spending for the Democratic candidate as a percent of the total spending in the district for the two major party candidates. Total favorable spending means money spent for the Democratic candidate and money spent against his/her Republican opponent. Note that in races with a contested primary (an uncommon occurrence), some primary spending may end up included in these totals, since the ability to extract that from the rest of the file is negligible given the way data is reported. 


\section{References}

Bartels, L. (1991). Instrumental and Quasi-Instrumental Variables. American Journal of Political Science, 35(3), 777-800.

Blanes i Vidal, J., Draca, M., \& Fons-Rosen, C. (2012). Revolving Door Lobbyists. American Economic Review, 102(7), 3731-3748.

Bloxham, E. (2014). Goldman Sachs and the Mystery of "Revolving Door" Bonuses. December 9. Fortune.com. Retrieved from http://fortune.com/2014/12/09/goldman-sachs-payrevolving-door/

Bonica, A. (2013). Ideology and Interests in the Political Marketplace. American Journal of Political Science, 57(2), 294-311.

Burnham, W. D., \& Ferguson, T. (2014). Americans Are Sick to Death of Both Parties: Why Our Political System Is in Worse Shape Than We Thought. AlterNet. December 18. Retrieved from http://www.alternet.org/americans-are-sick-death-both-parties-why-our-politicsworse-shape-we-thought

Cliff, A. D., \& Ord, J. K. (1981). Spatial Processes, Models and Applications. London: Pion.

Drutman, L. (2015). Despite Citizens United, Elections Aren't a Good Investment for Corporations. Washington Post. March 27. Retrieved from http://www.washingtonpost.com/opinions/despite-citizens-united-politics-isnt-a-goodinvestment-for-corporations/2015/03/27/f13e0d20-d26c-11e4-ab779646eea6a4c7_story.html

Ebbes, P. (2004). Latent Instrumental Variables: A New Approach to Solve for Endogenity. (Ph.D.), Groningen, Netherlands. Retrieved from https://www.rug.nl/research/portal/publications/pub\%282bb49ff4-cfff-4dcb-bc51$544 \mathrm{f0ca9f823 \% 29.html}$

Ebbes, P., Boechenholt, U., Wedel, M., \& Nam, H. (2009). A Bayesian Modeling Framework to Account for Regressor-Error Dependencies in Multilevel Models. Unpublished Technical Report.

Ebbes, P., Wedel, M., Boechenholt, U., \& Steerneman, T. (2005). Solving and Testing for Regressor (in) Dependence When No Instrumental Variables Are Available: With New Evidence For the Effect of Education on Income. Quantitative Marketing and Economics, 3, 365-392.

Eichengreen, B. (2015). Hall of Mirrors. New York: Oxford Univesity Press.

Epstein, G., \& Ferguson, T. (1991). Answers to Stock Questions: Fed Targets, Stock Prices, and the Gold Standard in the Great Depression. Journal of Economic History51(1), 190-200. 
Faccio, M., Masulis, R., \& McConnel, J. (2006). Political Connections and Government Bailouts. Journal of Finance, 61(6), 2597-2635.

Ferguson, T. (1995a). From 'Normalcy' To New Deal: Industrial Structure, Party Competition and American Public Policy in the Great Depression. In T. Ferguson, Golden Rule: The Investment Theory of Party Competition and the Logic of Money-Driven Political Systems (pp. 113-172). Chicago: University of Chicago Press.

Ferguson, T. (1995b). Golden Rule: The Investment Theory Of Party Competition And The Logic Of Money-Driven Political Systems. Chicago: University of Chicago Press.

Ferguson, T. (2015b). Big Money, Mass Media, and the Polarization of Congress. In W. Crotty (Ed.), Polarized Politics: The Impact of Divisiveness in the United States Political System (pp. 95-128). Boulder: Lynne Rienner.

Ferguson, T. (2016). Defying the Investors. Jacobin, June 28. Retrieved from https://www.jacobinmag.com/2016/06/ferguson-clinton-sanders-election-democratic-partytrump/

Ferguson, T., \& Chen, J. (2010). One, Two, Three...Many Tea Parties? A Closer Look at the 2010 Massachusetts Senate Race. Roosevelt Institute Working Paper. Retrieved From

http://rooseveltinstitute.org/wp-content/uploads/2010/04/a-closer-look-at-the-2010massachusetts-senate-race.pdf

Ferguson, T., \& Johnson, R. (2009). Too Big To Bail: The "Paulson Put," Presidential Politics, and the Global Financial Meltdown Part II: Fatal Reversal- Single Payer and Back. International Journal of Political Economy, 38(2), 5-45.

Ferguson, T., \& Johnson, R. (2013). When Wolves Cry 'Wolf': Systemic Financial Crises and the Myth of the Danaid Jar Monetary Economies of Production: Banking and Financial Circuits and the Role of the State Essays in Honor of Alain Parguez (pp. 73-98). Cheltenham, UK: Edward Elgar.

Ferguson, T., Jorgensen, P., \& Chen, J. (2012a). Cover Ups Are Worse Than Vanishing Data: The Facts About the FEC's Data Downloads. AlterNet. July 17. Retrieved from http://www.alternet.org/story/156355/cover_ups_are_worse_than_vanishing_data $\% 3 \mathrm{~A} \_\mathrm{t}$ he facts_about the fec $\% \mathrm{E} 2 \% 80 \% 99 \mathrm{~s}$ data_downloads

Ferguson, T., Jorgensen, P., \& Chen, J. (2012b). Response To the FEC on Missing Big Ticket Money Data. AlterNet. July 17. Retrieved from http://www.alternet.org/story/156368/response to the fec on missing big ticket mone y_data

Ferguson, T., Jorgensen, P., \& Chen, J. (2012c). Revealed: Key Files on Big-Ticket Political Donations Vanish at Federal Election Commission. AlterNet. July 16. Retrieved from http://www.alternet.org/story/156329/revealed\%3A_key files_on bigticket political_donations_vanish_at_federal_election_commission 
Ferguson, T., Jorgensen, P., \& Chen, J. (2013). Party Compeititon and Industrial Structure in the 2012 Elections: . International Journal of Political Economy, 42(2), 3-41.

Ferguson, T., \& Rogers, J. (1986). Right Turn: The Decline Of The Democrats And The Future of American Politics. New York: Hill \& Wang.

Ferguson, T., \& Voth, J. (2008). Betting On Hitler -- The Value of Political Connections in Nazi Germany. Quarterly Journal of Economics, 123, 101-137.

Gilens, M. (2012). Affluence and Influence. Princeton: Princeton University Press.

Gilens, M., \& Page, B. (2014). Testing Theories of American Interest Groups: Elites, Interest Groups, and Average Citizens. Perspectives on Politics, 12(3), 564-581.

Grossman, S., \& Stiglitz, J. (1980). On the Impossiblity of Informationally Efficient Markets. American Economic Review, 70(3), 393-408.

Hueter, I. (2016). Latent Instrumental Variables: A Critical Review. Institute for New Economic Thinking Working Paper No. 46. Retrieved from ineteconomics.org/ideaspapers/research-papers/latent-instrumental-variables-a-critical-review.

Jacobson, G. (2006). Campaign Spending Effects in U.S. Senate Elections: Evidence From the National Annenberg Election Survey. Electoral Studies, 25, 195-226.

Jacobson, G. (2013). The Politics of Congressional Elections. Boston: Pearson.

Jones, M., \& Jorgensen, P. (2012). Mind the Gap: Political Advertisements and Congressional Election Results. Journal of Political Marketing, 11, 165-188.

Jorgensen, P. (2013). Institutional Corruption and the Pharmaceutical Industry. Journal of Law, Medicine, and Ethics, 561-570.

Krasnow, J. (2004). Introduction -- Political Scientists in McConnell vs. FEC. PS: Political Scientists and Politics(October), 769-770.

La Raja, R. J. (2013). Richer Parties, Better Parties? Party-Centered Campaign Finance Laws and American Democracy. The Forum, 11(3), 313-338.

Mayer, J. (2016). Dark Money. New York: Doubleday.

Mian, A., Sufi, A., \& Trebbi, F. (2008). The Political Economy of the U.S. Mortgage Default Crisis. National Bureau of Economic Research. Working Paper 14468.

Milyo, J. (2013). Campaign Spending and Electoral Competition: Towards More Policy Relevant Research. Final Draft of Article to be published in The Forum: A Journal of Applied Research in Contemporary Politics, 11(3), 437-454. Retrieved from http://www.cfinst.org/pdf/papers/04_Milyo_Competition.pdf 
Moore, D., \& Saad, L. (1997). The Generic Ballot in Midterm Congressional Elections: Its Accuracy and Relationship to House Seats. Public Opinion Quarterly, 61(4), 603-614.

Moran, P. A. P. (1950). Notes on Continuous Stochastic Phenomena. Biometrika, 17(1), 17-23.

Parti, T., \& Pallmer, A. (2014). Tea Party Fumes Over Campaign Finance Plan. Politico. December 11. Retrieved from http://www.politico.com/story/2014/12/tea-party-revoltsover-campaign-finance-plan-113520.html

Piketty, T. (2014). Capital in the Twenty-First Century (A. Goldhammer, Trans.). Cambridge: Harvard University Press.

Rhode, P. W., \& Strumpf, K. (2004). Historical Presidential Betting Markets. Journal of Economic Perspectives, 18(2), 127-142.

Rhode, P. W., \& Strumpf, K. (2007). Manipulating Political Stock Markets: A Field Experiment and a Century of Observational Data. University of North Carolina Working Paper. Retrieved from http://www.unc.edu/ cigar/papers/ManipNBER.pdf

Rhode, P. W., \& Strumpf, K. (2008). Historical Political Futures Markets: An International Perspective. National Bureau of Economic Research. Working Paper 14377.

Rove, K. (2010). Polling News \& Notes. April 8. Retrieved from https://d3o7ok5jv7btfa.cloudfront.net/polling notes/0000/0093/KR PN_N.pdf

Rutz, O. J., Bucklin, R. E., \& Sonnier, G. P. (2012). A Latent Instrumental Variables Approach to Modeling Keyword Conversion in Paid Search Advertising. Journal of Marketing Research, XLIX, 306-319.

Sherman, A. (2013). Jonathan Karl Looks Back at the Generic Ballot in 1994 and 2010. Punditfact. November 3.

Sachs, Jeffrey. (2011) The Price of Civilization. New York: Random House

Snowberg, E., Wolfers, J., \& Zitzewitz, E. (2012). Prediction Markets for Economic Forecasting. Brookings Institution. Retrieved from http://www.brookings.edu/ /media/research/files/papers/2012/6/13\%20prediction $\% 20$ markets $\%$ 20wolfers/13\%20prediction $\% 20$ markets $\% 20$ wolfers.pdf

Stiglitz, J. (2013). The Price of Inequality. New York: W.W. Norton.

Stock, J. H., \& Watson, M. W. (2010). Introduction to Econometrics (3rd ed.). Boston: Pearson Addison Wesley.

Tahoun, A. and Vasvari F. (2016). Political Lending. Institute for New Economic Thinking Working Paper No. 47. Retrieved from https://www.ineteconomics.org/ideaspapers/research-papers/political-lending. 
Temin, P. (2016). The American Dual Economy: Race, Globalization, and the Politics of Exclusion. Institute for New Economic Thinking, Working Paper No. 26. Retrieved from https://www.ineteconomics.org/uploads/papers/The-American-Dual-Economy-RaceGlobalization-and-the-Politics-of-Exclusion.pdf

Tooze, A. (2014). The Deluge. New York: Viking.

Wolfers, J., \& Zitzewitz, E. (2004). Prediction Markets. Journal of Economic Perspectives, $18(2), 107-126$.

Zhang, J., Wedel, M., \& Pieters, R. (2009). Sales Effects of Attention to Feature Advertisements: A Bayesian Mediation Analysis. Journal of Marketing Research, XLVI, 669-681.

Ziobrowski, A. J., Boyd, J. W., Cheng, P., \& Ziobrowski, B. J. (2011). Abnormal Returns From Common Stock Investments of Members of the United States House of Representatives. 13(1), 1-22.

Ziobrowski, A. J., Cheng, P., Boyd, J. W., \& Ziobrowski, B. J. (2004). Abnormal Returns From the Common Stock Investments of the United States Senate. Journal of Financial and Quantitative Analysis, 39, 661-676. 